\title{
Gladiopycnodontidae, a new family of pycnodontiform fishes from the Late Cretaceous of Lebanon, with the description of three genera
}

\author{
Louis TAVERNE ${ }^{1} \&$ Luigi CAPASSO ${ }^{2}$ \\ ${ }^{1}$ Royal Belgian Institute of Natural Sciences, Department of Paleontology, Vautierstreet, 29, \\ B-1000 Brussels, Belgium. E-mail: louis.taverne@gmail.com \\ ${ }^{2}$ Museo Universitario dell’Universitá "G. d'Annunzio" di Chieti-Pescara, Piazza Trento e Trieste 1, \\ I-66100 Chieti, Italy. E-mail: 1capasso@unich.it \\ ${ }^{1}$ urn:1sid:zoobank.org:author:0CF81641-1DD1-4CBD-9735-F1FE7EB0BCF5 \\ ${ }^{2}$ urn:1sid:zoobank.org:author:C79C14CF-C1D7-48E3-9BA9-CAD8AA0909F7
}

\begin{abstract}
The osteology of Gladiopycnodus karami gen. et sp. nov., of Monocerichthys scheuchzeri gen. et sp. nov. and of Rostropycnodus gayeti gen. et sp. nov., three new fossil fishes from the marine Cenomanian (Late Cretaceous) of Lebanon, is studied in detail. Some of their cranial characters and the presence of a postcoelomic bone clearly refer these fishes to the order Pycnodontiformes. However, they differ from all other described Pycnodontiformes by two important characters. Their snout is elongated as a rostrum, formed by the enlarged prefrontal and the toothless premaxilla, with this premaxilla sutured by its upper margin to the lower margin of the prefrontal. Their pectoral fin is replaced by a strong spine articulated with the cleithrum. These two apomorphies justify the erection of a new family, the Gladiopycnodontidae. The skull of Monocerichthys scheuchzeri sp. nov. does not differ greatly from a classical pycnodontiform skull and this species seems to be the more primitive member of this new family. Gladiopycnodus karami gen. et sp. nov. and Rostropycnodus gayeti gen. et sp. nov. are much more specialized. They share some apomorphies not present in Monocerichthys scheuchzeri gen. et sp. nov., i. e., an extremely long rostrum and an elongated first anal pterygiophore that sustains with the postcoelomic bone a strong and long anal spine. Gladiopycnodontidae fam. nov. and Coccodontidae share a series of apomorphies that justify the erection of a new superfamily, Coccodontoidea, grouping these two families.
\end{abstract}

Key words. Pycnodontiformes, Coccodontoidea superfam. nov., Gladiopycnodontidae fam. nov., Gladiopycnodus karami gen. et sp. nov., Monocerichthys scheuchzerii gen. et sp. nov., Rostropycnodus gayeti gen. et sp. nov., osteology, relationships, Cenomanian, Lebanon.

Taverne L. \& Capasso L. 2013. Gladiopycnodontidae, a new family of pycnodontiform fishes from the Late Cretaceous of Lebanon, with the description of three genera. European Journal of Taxonomy 57: 1-30. http:// dx.doi.org/10.5852/ejt.2013.57

\section{Introduction}

Pycnodontiform fishes are by far the largest marine halecostome fossil lineage, that range in time from the Late Triassic to the Middle Eocene and have an almost worldwide distribution (Nursall 1996a; 
Kriwet 2001). They are often found in marine and more rarely in brackish or freshwater deposits. Most of them possess a deep and laterally compressed body. They generally have a durophagous mode of feeding thanks to their molariform teeth on the vomer and the prearticulars (Nursall 1996a: fig. 3). Some specialists consider them as closely related to the teleosts (e.g., Nursall 2010).

For a very long time, all pycnodontiform fishes were ranged in the order Pycnodontiformes (e.g., Nursall 1996b; Poyato-Ariza \& Wenz 2002; Kriwet 2005). But recently, a new superorder Pycnodontomorpha was erected to accomodate them, comprising two orders: the Gyrodontiformes for the families Mesturidae and Gyrodontidae and the Pycnodontiformes (new usage for the former Pycnodontoidei) for the families Brembodontidae, Coccodontidae, Trewavasiidae and Pycnodontidae (Nursall 2010). However, some specialists disagree with such a division and consider the Gyrodontiformes as polyphyletic (PoyatoAriza pers. com., April 2013).

Pycnodontiform fishes are well known in the marine Late Cretaceous of Lebanon (e.g., Pictet 1850; Davis 1887, 1890; Hay 1903; Poyato-Ariza \& Wenz 2002, 2005; Forey et al. 2003; Capasso et al. 2009; Gayet et al. 2012) and they include a few highly specialized families, such as Gebrayelichthyidae (Nursall \& Capasso 2004) and Coccodontidae [including Trewavasiidae] (Gayet 1984; Kriwet 2004; Nursall \& Capasso 2008; Capasso et al. 2010).

Capasso's paleontological collection in Chieti (Italy) contains numerous still undescribed pycnodontiform fishes from Lebanon. Some of them represent a new remarkable family containing about ten genera. The fishes belonging to these genera are not deep-bodied, but fusiform in shape, except for one very specialized genus with a rounded body. Their snout is more or less elongated, forming a rostrum that anteriorly protrudes above the lower jaw. The anterior extremity of this rostrum is constituted by the enlarged prefrontal only and not by the premaxilla that usually assumes this role in a pycnodontiform snout. The long, broad, toothless premaxilla is located below the prefrontal and is sutured along its upper margin to this prefrontal and so strengthens the rostrum. Their pectoral fin is lost and replaced by a strong spine. Some species of the new family possess frontal, occipital, nuchal and cleithral horns or spines. The Cenomanian Lebanese species "Coccodus" lindstroemi Davis, 1890 (not a true Coccodus Pictet, 1850, see Poyato-Ariza \& Wenz 2002: 145) belongs to this new lineage (Taverne \& Capasso, work in prep.).

The aim of our paper is to describe three members of this new family, the less specialized and the two most specialized genera. We will also discuss the systematic position of the family within pycnodontiform fishes. Other papers are in preparation and will complete the study of the group.

\section{Material and methods}

The specimens herein studied belong to the Luigi Capasso collection (CLC) in Chieti (Italy), that is legally registered by a decree of the Ministero per i Beni e le Attività Culturali, date of October $11^{\text {th }}$, 1999, following the disposition of the Italian law 1089/39. The Soprintendenza per i Beni Archeologici dell'Abruzzo - Chieti has authorized the authors to study this collection by a letter bearing the date of May 5 $5^{\text {th }}, 2011$ (reference: MBAC-SBA-ABR PROT 0004537 05/05/2011 Cl. 34.25.01/2.1).

The specimens were studied with a Leica-Wild M 8 stereo microscope. The figures were drawn by the first author (LT). Aspersions with ethanol were used to improve the observations.

\section{List of abbreviations used in text-figures}

$\begin{array}{lll}\text { AN } & = & \text { angular } \\ \text { ART } & = & \text { articular } \\ \text { ASPH } & = & \text { autosphenotic } \\ \text { CLT } & = & \text { cleithrum }\end{array}$


TAVERNE L. \& CAPASSO L., Gladiopycnodontidae fam. nov. (Pisces) from the Cretaceous of Lebanon

\begin{tabular}{|c|c|c|}
\hline DHYOM & $=$ & dermohyomandibula \\
\hline $\mathrm{DN}$ & $=$ & dentary \\
\hline DPTE & $=$ & dermopterotic \\
\hline DSOC & $=$ & dermosupraoccipital \\
\hline DSPH & $=$ & dermosphenotic \\
\hline ENPT & $=$ & entopterygoid (= endopterygoid) \\
\hline EPCO 1-6 & $=$ & epichordals 1 to 6 \\
\hline FR & $=$ & frontal \\
\hline HAEM & $=$ & haemal arch \\
\hline HAEMEP & $=$ & haemal spine \\
\hline HCLT & $=$ & hypercleithrum (= supracleithrum) \\
\hline HYCO 1-12 & $=$ & hypochordals 1 to 12 \\
\hline HYOM & $=$ & hyomandibula \\
\hline IORB $1-5$ & $=$ & infraorbitals 1 to 5 \\
\hline LEP & $=$ & lepidotrichium \\
\hline METH & $=$ & mesethmoid \\
\hline MPT & $=$ & metapterygoid \\
\hline MX & $=$ & maxilla \\
\hline NEUR & $=$ & neural arch \\
\hline NEUREP & $=$ & neural spine \\
\hline NU & $=$ & nuchal horn \\
\hline OP & $=$ & opercle \\
\hline OSPH & $=$ & orbitosphenoid \\
\hline PA & $=$ & parietal \\
\hline PCLT & $=$ & postcleithrum \\
\hline PCOEL & $=$ & postcoelomic bone \\
\hline PELV & $=$ & pelvic bones \\
\hline PMX & $=$ & premaxilla \\
\hline POP & $=$ & preopercle \\
\hline PRART & $=$ & prearticular \\
\hline PRFR & $=$ & prefrontal (= laterodermethmoid ?) \\
\hline PS & $=$ & parasphenoid \\
\hline PT & $=$ & posttemporal \\
\hline QU & $=$ & quadrate \\
\hline RAD & $=$ & pterygiophores \\
\hline RAD d. $1-13$ & $=$ & dorsal pterygiophores (= radials) 1 to 13 \\
\hline RAD a & $=$ & anal pterygiophores \\
\hline RAD 1 & $=$ & first anal pterygiophore \\
\hline $\mathrm{SC} \mathrm{b}$ & $=$ & body scale \\
\hline $\mathrm{SC} \mathrm{c}$ & $=$ & caudal scale \\
\hline SCL & $=$ & sclerotic bone \\
\hline SCU d. & $=$ & dorsal ridge scute \\
\hline SCU p. & $=$ & pelvic scute \\
\hline SCU po. & $=$ & postcloacal scute \\
\hline SPI a. & $=$ & spine of the anal fin \\
\hline SPI p. & $=$ & pectoral spine \\
\hline ST & $=$ & supratemporal \\
\hline SY & $=$ & symplectic \\
\hline VO & $=$ & vomer \\
\hline ol. f. & $=$ & olfactive fossa \\
\hline
\end{tabular}




\title{
Results
}

\author{
Subclass Actinopterygii Klein, 1885 \\ Series Neopterygii Regan, 1923 \\ Division Halecostomi Regan, 1923 sensu Patterson 1973 \\ Superorder Pycnodontomorpha Nursall, 2010 \\ Order Pycnodontiformes Berg, 1937 sensu Nursall 2010 \\ Superfamily Coccodontoidea superfam. nov. \\ urn:1sid:zoobank.org:act:F0BC595E-F862-4373-860B-CB749B1EC5E4
}

\section{Diagnosis}

Pycnodontiformes primitively with a fusiform body, devoid of dorsal and ventral apex. Skull bearing horns or spines. Dermohyomandibula present. Preopercle enlarged and much larger than the exposed part of the hyomandibula-dermohyomandibula. Small opercle present. Infraorbitals covering only a small part of the cheek. Large pectoral girdle closely associated to the skull, forming a sort of cephalo-thorax. Large supratemporal articulated with the dermosupraoccipital, the parietal and the dermopterotic. Large posttemporal sutured to the supratemporal. Coronoid process of the prearticular weakly developed. Enlarged hypercleithrum. Cleithrum greatly hypertrophied, with a ventral posterior process. Less than 20 vertebral segments before the epichordal series. Neural and haemal spines short. Dorsal fin primitively short and located on the middle of the back. Anal fin primitively short and largely separated from the tail. Last hypochordal elements enlarged but not hypertrophied. One or no postcloacal scute.

Family Gladiopycnodontidae fam. nov. urn:1sid:zoobank.org:act:66F04581-AFC7-47B5-A6E8-7FB0935ADD81

\section{Diagnosis}

Small Coccodontoidea superfam. nov.. Snout elongated and forming a rostrum outpacing anteriorly the lower jaw level. Anterior tip of the rostrum formed by the long and broad prefrontal only. Premaxilla long, broad, toothless and sutured all along its dorsal margin with the prefrontal. Pectoral fin lost and replaced by a strong spine articulated with the cleithrum. Body entirely covered with small flake-like scales or with scutes.

Genus Gladiopycnodus gen. nov. urn:1sid:zoobank.org:act:623891D8-C2AE-4814-91C3-CBE48D098B88

\section{Type-species}

Gladiopycnodus karami gen. et sp. nov. (by monotypy)

\section{Diagnosis}

As for the species (monospecific genus).

\section{Etymology}

From the Latin gladius, sword, referring to the shape of the pectoral and anal spines. The generic name Pycnodus is added. 
TAVERNE L. \& CAPASSO L., Gladiopycnodontidae fam. nov. (Pisces) from the Cretaceous of Lebanon

\author{
Gladiopycnodus karami gen. et sp. nov. \\ Figs 1-6 \\ urn:Isid:zoobank.org:act:BE468D57-6344-4EA5-8F40-2A0646799E2C
}

\title{
Diagnosis
}

Gladiopycnodontid with an extremely elongated snout, forming a sword-like rostrum horizontally oriented and greatly outpacing the lower jaw level. Anterior tip of the prefrontal ending in an acuminate point. Frontal long and narrow. Dermosphenotic and dermopterotic partly fused. Oral border of premaxilla and maxilla toothless but bearing very small spines. Five infraorbitals, the first one larger than the others. Large lower jaw horizontally oriented. Large prearticular bearing molariform teeth. Preopercle greatly hypertrophied, with an elongated and denticulated lower margin forming the ventral border of the skull behind the lower jaw. Cleithrum vertically oriented. Strong pectoral spine. Reduced pelvic girdle present. Nuchal horn absent. Long and robust postcoelomic bone. Dorsal fin with short isolated rays forming a series of finlets. Anal fin beginning with an extremely long and strong spine that greatly outpaces the tail level. Only a few short soft anal rays. Caudal fin with a convex posterior border. Large paired dorsal scutes between the skull and the tail. Body completely covered with small flakelike scales irregularly imbricated. Large rounded scales on the caudal peduncle. Two pelvic scutes. One postcloacal scute. No scute on the ventral margin of the body in the caudal region.

\section{Etymology}

The species name of the new Lebanese fossil fish is dedicated to Youssef Bey Karam (1823-1889), the famous hero of Lebanon who lived during the time this country was ruled by the Ottoman Empire.

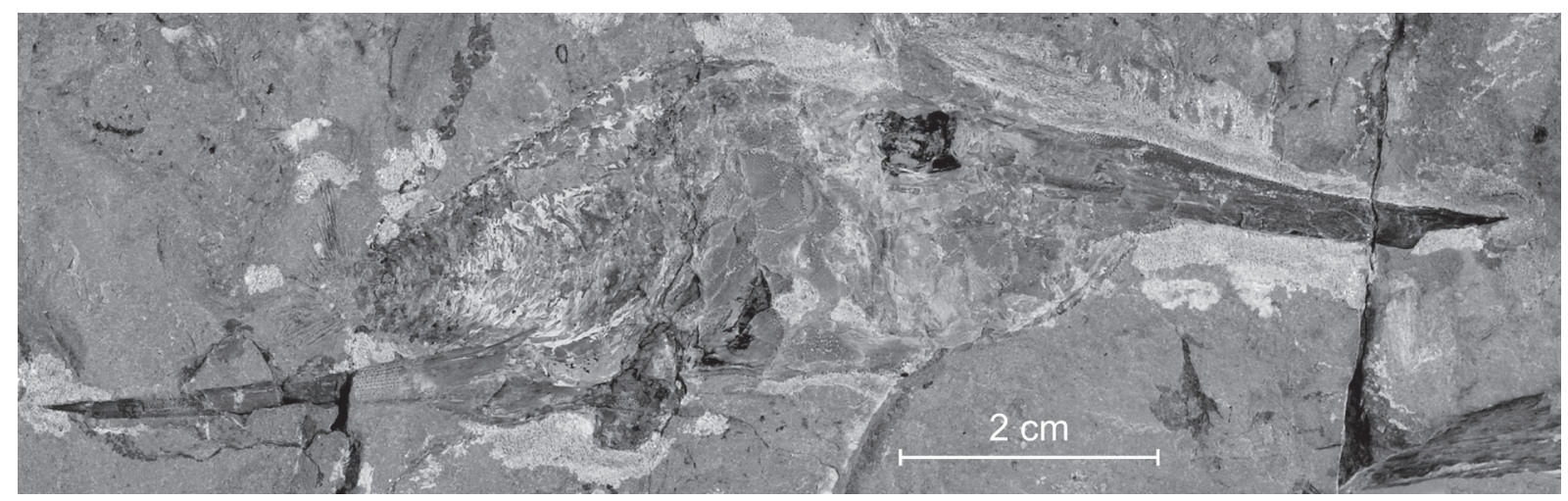

Fig. 1. Gladiopycnodus karami gen. et sp. nov. Holotype CLC S-393.

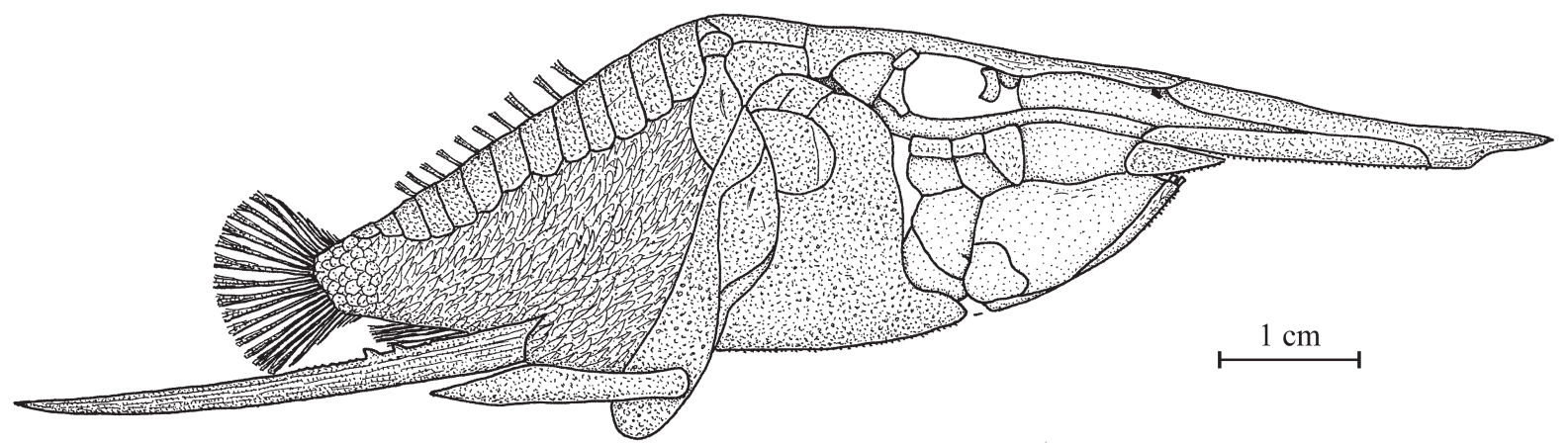

Fig. 2. Gladiopycnodus karami gen. et sp. nov. Reconstruction of holotype CLC S-393. 


\section{Holotype}

Sample CLC S-393, a complete specimen seen by its right side (Figs 1-2). Total length (the anal spine comprised): $117 \mathrm{~mm}$. Total length (only skull and body): $98 \mathrm{~mm}$.

\section{Other material}

Three other specimens of the new species exist in private collections and, unfortunately, are not accessible for scientific study. However, the authors received good photos of these three specimens and a few anatomical details, not well preserved on the holotype, were revealed by their observation.

\section{Formation and locality}

Marine Upper Cenomanian, Haqel, Lebanon.

\section{Holotype morphometric data}

The morphometric data are given in \% of the holotype standard length $(91 \mathrm{~mm})$.

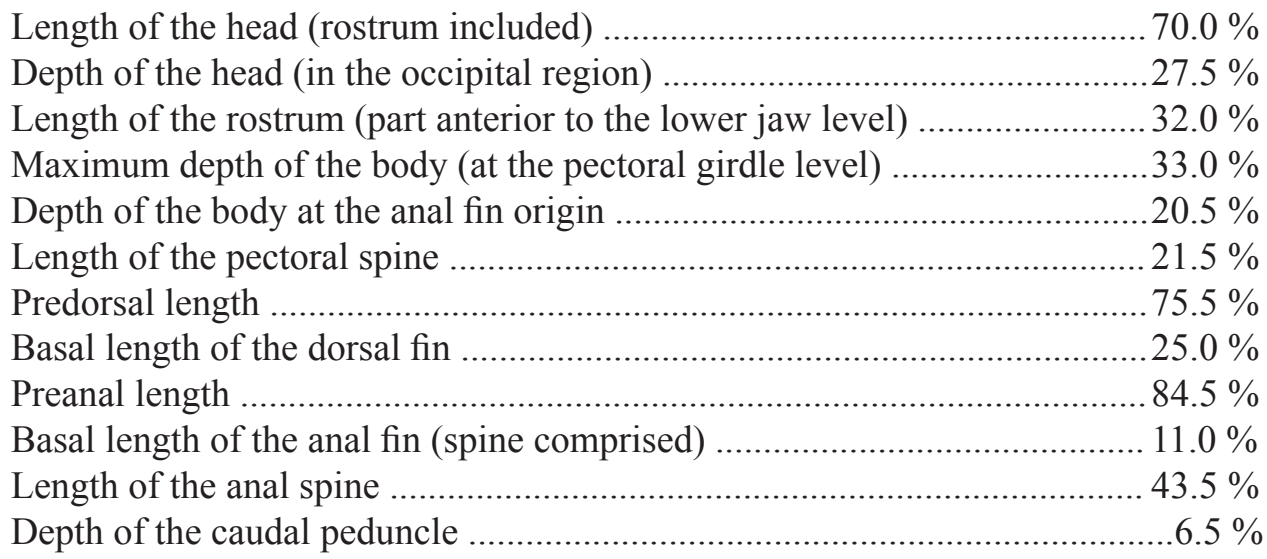

\section{Osteology}

\section{The skull (Fig. 3)}

The head, rostrum comprised, is twice as long as the body. The dermal bones of the skull are ornamented with small tubercles and a few thin ridges on the anterior portion of the prefrontal.

The snout is greatly elongated, forming a sword-like rostrum that is horizontally oriented in the same axis as the braincase and the axial skeleton. This rostrum consists of the prefrontals, the premaxillae, the mesethmoid, the parasphenoid and probably the vomer. All these bones are very long. The most anterior parts of the mesethmoid and of the parasphenoid are hidden by the prefrontal and the premaxilla that are connected together. The vomer is hidden by the premaxilla. The pointed anterior tip of the rostrum is only formed by the prefrontal. The olfactive foramen on the mesethmoid is located at the level of the suture between the frontal and the prefrontal.

The skull roof comprises the dermosupraoccipital and paired frontals, parietals, dermopterotics and dermosphenotics. The frontal is flat, very long but narrow. Posteriorly, the bone is a little broader and contacts the dermosupraoccipital and the parietal. It also overhangs the well developed triangular autosphenotic. The dermosupraoccipital exhibits a pointed posterior corner but no real horn. This posterior spiny process reaches the first dorsal scute. The parietal is a large bone. It is not possible to say if a brush-like posterior process is present or not on the parietal, the region being hidden by the pectoral girdle and the first dorsal scutes. The zone where a dermocranial fenestra is present in some pycnodontiform fishes is broken on the holotype. However, photos of other specimens clearly show that 
such a fenestra does not exist in this species. The dermopterotic and the dermosphenotic are smaller bones than the parietal. They are fused together dorsally but remain separated ventrally.

The parasphenoid is long and toothless. A very small orbitosphenoid is present just behind the mesethmoid. The other endocranial bones of the braincase are hidden by the preopercle and the hyomandibuladermohyomandibula.

The upper jaw is a part of the rostrum and, thus, is located before the lower jaw, which does not participate in the rostrum. The premaxilla is a very long and rather broad bone that is located below the prefrontal and is sutured with it along its upper margin. The maxilla lies under the posterior extremity of the premaxilla. It is a much shorter bone shaped as a lance head with the point anteriorly oriented. The oral border of both bones bear very small spines but there are no true teeth.

The lower jaw is large and triangular in shape. The dentary is a small but long bone, reduced to its ventral branch and bearing two incisiform prehensile teeth. The upper part of the anterior margin of the dentary is ornamented with a few very small spines. The prearticular is the largest component of the lower jaw. Its inner face is never visible, neither on the holotype nor on the other specimens. However, some large molariform teeth are visible under a broken part of the prearticular on the photo of one specimen. The angular is as deep as long. The articular is longer but narrow.

Both the quadrate and the symplectic articulate with the lower jaw. As usual in pycnodontiform fishes, the quadrate does not possess an ossified quadratic process. The symplectic is a very robust curved bone pressed against the quadrate. A small metapterygoid overhangs the quadrate. The entopterygoid is a large and broad bone as long as the lower jaw. No ectopterygoid is visible.

There are five infraorbitals and a sclerotic ring. The ventral part of the first infraorbital is missing on the holotype, but an enlarged triangular-shaped first infraorbital is visible on the photo of one of the other specimens. However, this bone covers only a very small part of the cheek. The four other infraorbitals are well developed but narrower than the first one and more or less reduced to their neurodermic component.

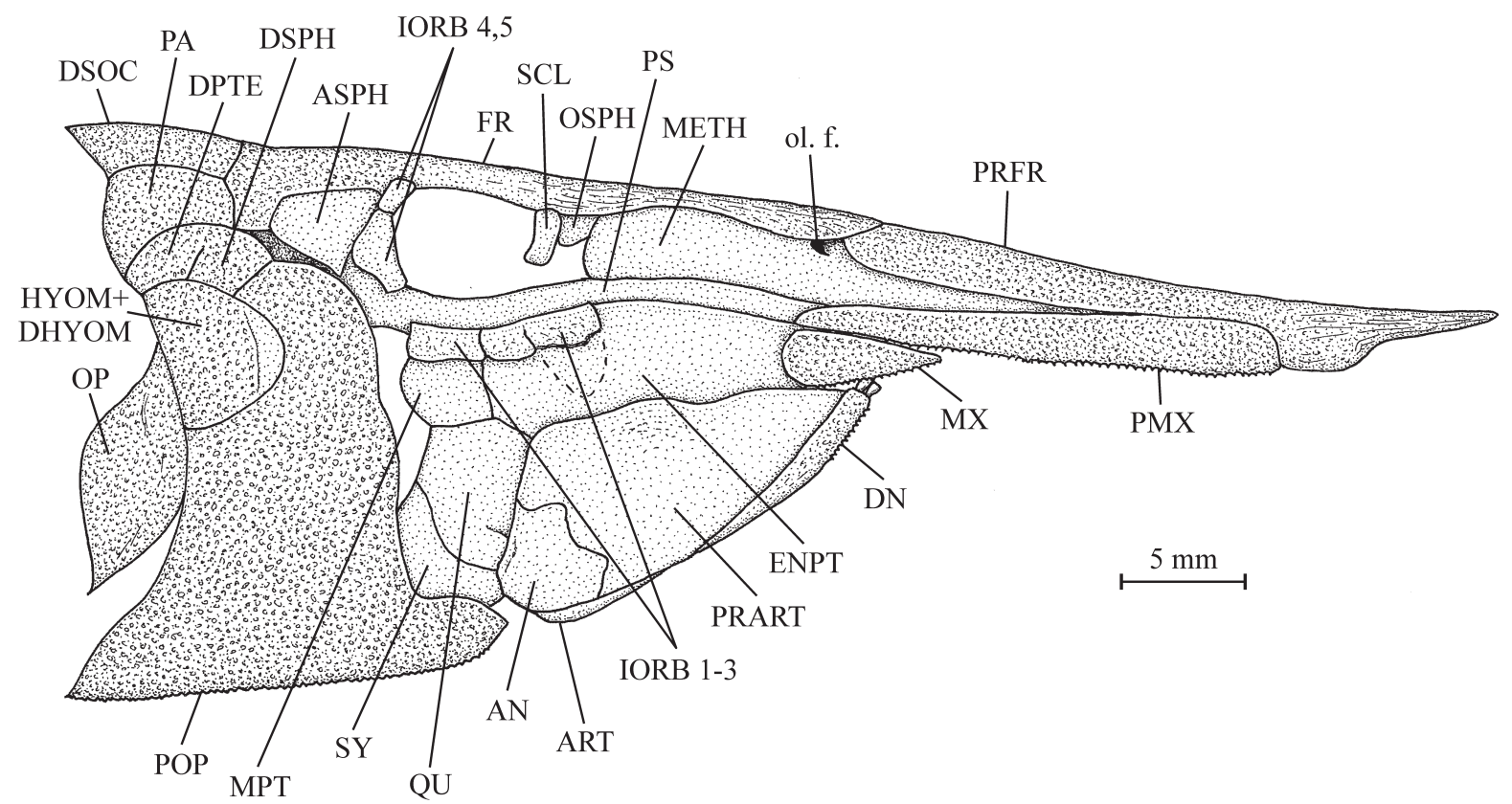

Fig. 3. Gladiopycnodus karami gen. et sp. nov. Reconstruction of the skull of holotype CLC S-393. 
The greatly hypertrophied preopercle is by far the largest bone of the skull, all together deep and broad, with a very elongated ventral border that forms the ventral margin of the skull. Dorsally, the preopercle reaches the dermosphenotic and the autosphenotic and exhibits a posterior hollow in which the hyomandibula-dermohyomandibula fits. The opercle is well developed but a lot smaller than the preopercle. It is an ovoid bone with its dorsal and ventral extremities acuminate. The branchiostegal rays are not visible.

The hyomandibula and dermohyomandibula are intimately fused in a pyriform-shaped bone of the same size as the opercle and thus much smaller than the preopercle. Within this double composed bone, the small hyomandibula is anteriorly located and has a smooth surface, whereas the larger dermohyomandibula is posteriorly located and has a granulated surface. It is possible that a ventral branch of the hyomandibula is hidden by the preopercle. The hyoid bar is not visible.

\section{The girdles (Figs 2, 4-5)}

The pectoral girdle is pressed against the skull. The dermal bones of the pectoral girdle are ornamented with small tubercles as those on the skull. The cleithrum is by far the largest element of the girdle. It is a very deep, broad and vertically oriented bone. There is a shortening in its upper part that creates a sort of hollow in its anterior margin. The opercle fits in this hollow. The posttemporal is a very small and more or less rounded bone wedged between the parietal, the supraoccipital and the first dorsal scute. The hypercleithrum (= supracleithrum) is larger and amphora-like in shape. The pectoral fin is lost and replaced by a big pointed spine, articulated on the cleithrum.

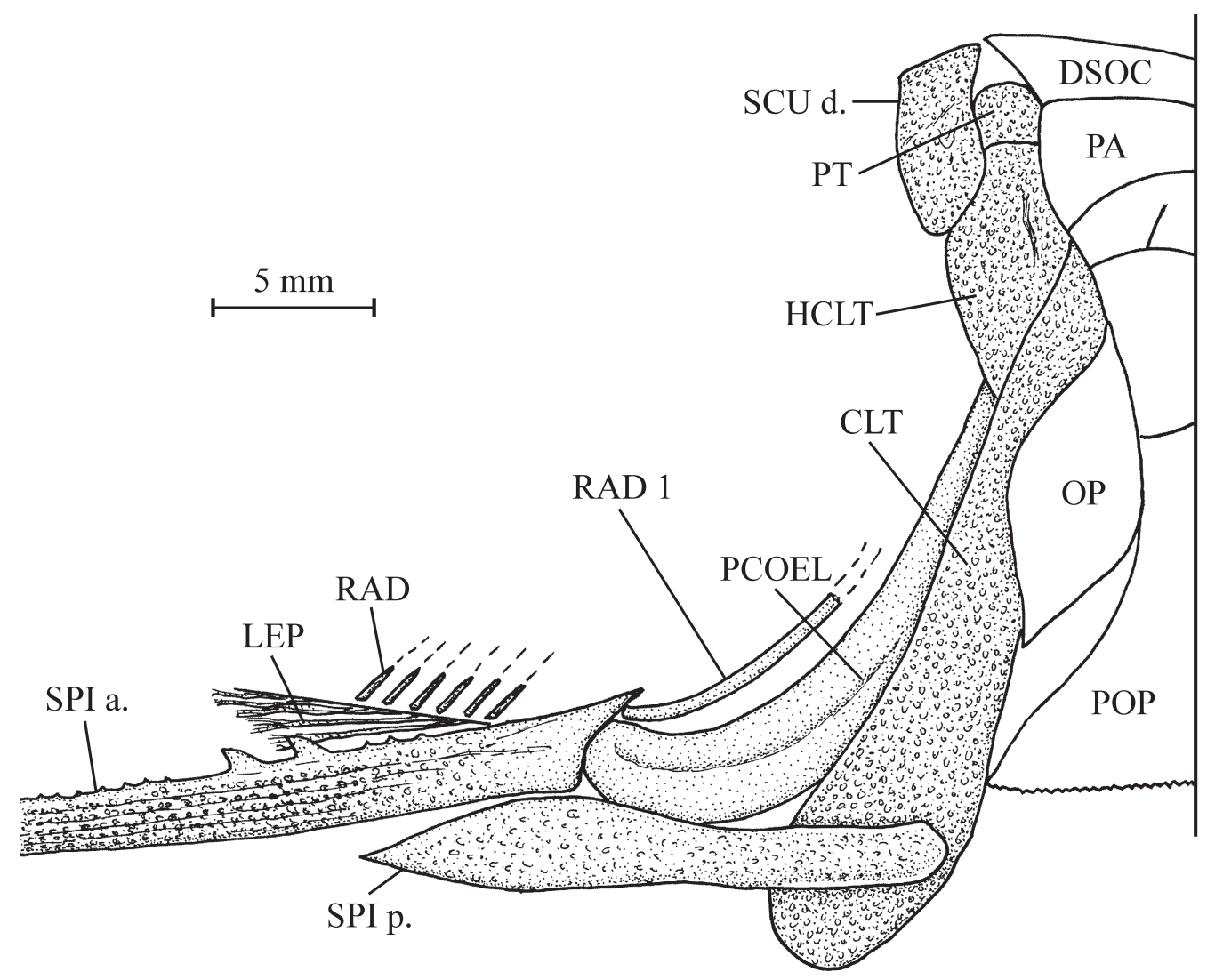

Fig. 4. Gladiopycnodus karami gen. et sp. nov. Reconstruction of the pectoral girdle and of the anal fin of holotype CLC S-393. 
The pelvic girdle is hidden on the holotype because the fossilisation has pressed the pectoral and anal spines against each other. However, on one specimen seen in photo, two small, obliquely oriented pelvic bones are clearly visible between these two spines and some fragments of short pelvic rays appear under the pelvic scutes.

\section{The axial skeleton}

The body is fusiform. It is difficult to describe the axial skeleton in a detailed way, as it is generally more or less covered by the scales and it is not possible to count the vertebral segments. The holotype shows a few fragments of neural and haemal spines. On one of the specimens seen on photo, many scales on the body are lost and we can observe that the notochord is nearly completely surrounded by the neural and haemal arches. The neural and haemal spines are well developed but rather short. Each of them bears a broad anterior wing. The spines are not interlocked together by interdigitating sutures.

The presence of ribs is uncertain, the situs viscerum being hidden by the gigantic preopercle, the opercle and the pectoral girdle.

The post-coelomic bone is long and very robust. It reaches the vertebral axis dorsally and the inferior border of the fish ventrally. Its broad ventral part is backwardly curved.

\section{The dorsal and anal fins (Figs 2, 4)}

The dorsal fin is composed of about ten very short, branched rays. They rise between the paired dorsal scutes and remain isolated from each other, forming a series of dorsal finlets. In one of the photographed specimens, the last dorsal rays near the tail are not isolated but pressed together.

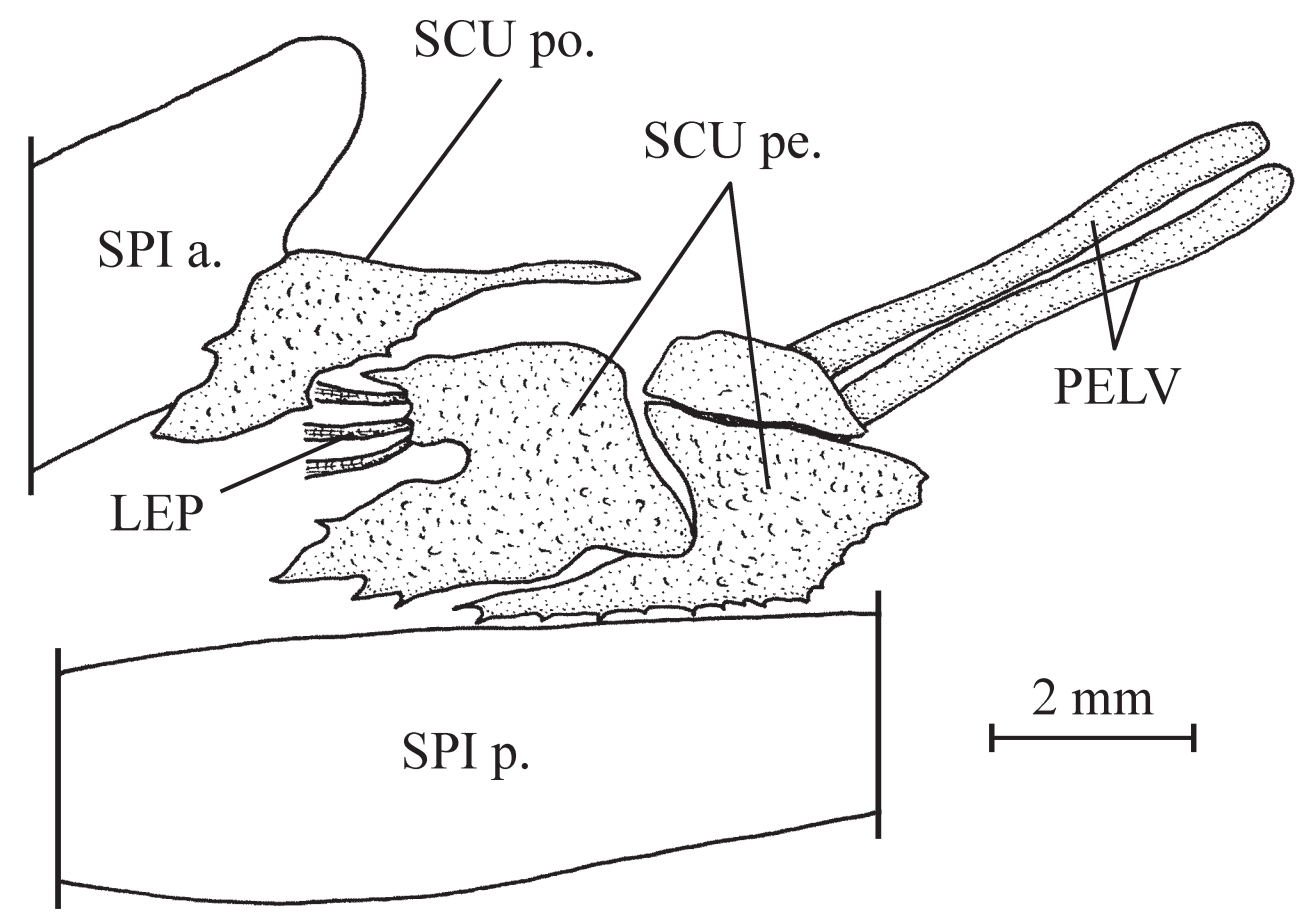

Fig. 5. Gladiopycnodus karami gen. et sp. nov. The pelvic girdle as seen on the photo of a specimen in a private collection. 
The anal fin begins with a very strong and extremely long spine that extends backward greatly beyond the tail. A few short, branched rays follow this spine. The surface of the spine is ornamented with granulations ranged in regular ranks. The upper border of the spine bears two big and a series of small denticles. The spine is articulated on the post-coelomic bone and on the first pterygiophore, which is longer and separated from the other anal pterygiophores.

\section{The caudal skeleton (Fig. 2)}

The caudal skeleton is covered by scales and thus remains unknown.

The small caudal fin is not forked. Its posterior border is convex. The holotype has 17 principal rays, of which the most external dorsal and ventral ones are segmented, pointed and a little shorter than the 15 others, that are segmented and branched. There are 5 dorsal and 5 ventral procurrent rays.

\section{Squamation (Figs 5-6)}

Gladiopycnodus karami gen. et sp. nov. possesses four different types of scutes and scales.

The dorsal margin of the fish is covered by large and deep paired scutes that are ornamented with tubercles and some small irregular ridges. The two last scutes are less deep than the more anterior pieces of the series. The holotype bears thirteen pairs of these dorsal scutes. One sample seen on photo has about twenty paired dorsal scutes. This difference in the number of dorsal scutes perhaps reflects an individual variation within the species, but could have also a sexual origin. The ventral margin of the caudal region of the fish is devoid of such scutes.

The body is entirely covered by small flake-like scales that are irregularly imbricated. Most scales have a smooth posterior border, but some of them bear a few very small spines on their posterior border.

A series of large rounded scales cover the caudal peduncle. They are ornamented with tubercles.

Two pelvic scutes and one postcloacal scute are visible on the photo of the specimen that shows the pelvic girdle. A part of their margins is spiny.
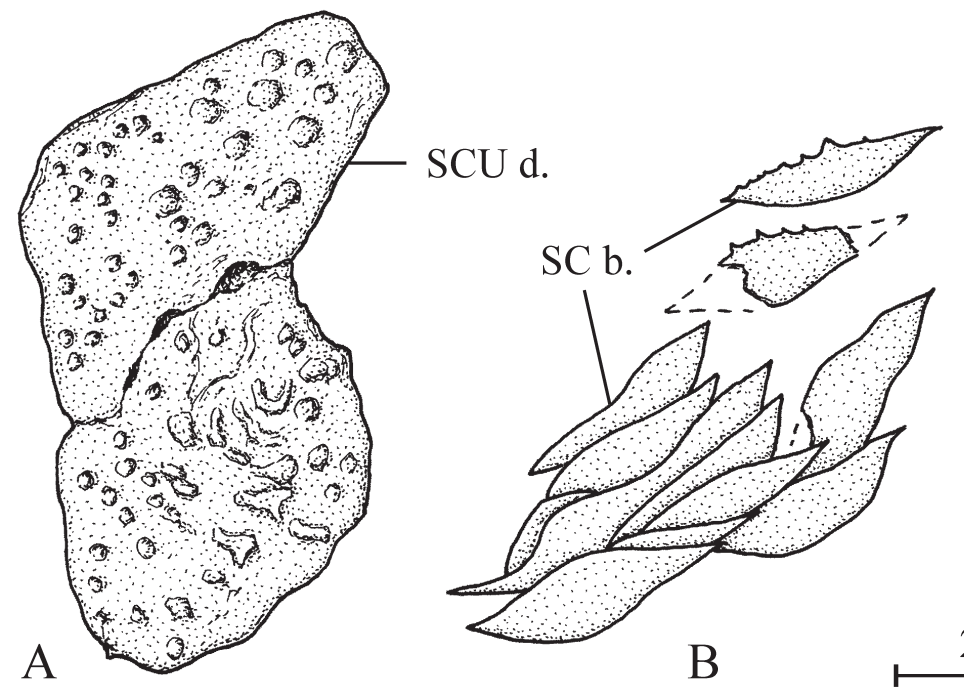

$\mathrm{SC}$ c.

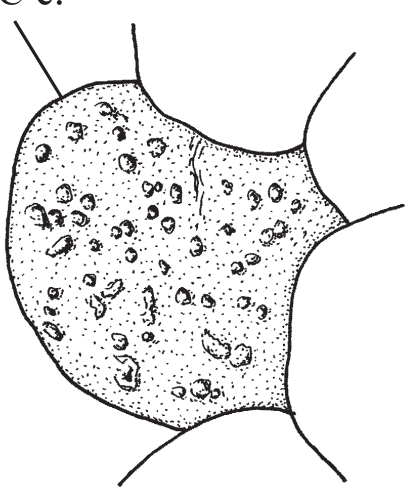

$\mathrm{mm}$

Fig. 6. Gladiopycnodus karami gen. et sp. nov., holotype CLC S-393. A. First dorsal scute. B. Some scales of the body. C. One scale near the caudal fin. 
TAVERNE L. \& CAPASSO L., Gladiopycnodontidae fam. nov. (Pisces) from the Cretaceous of Lebanon

Genus Monocerichthys gen. nov. urn:1sid:zoobank.org:act:2D642D4F-2B85-4838-90BD-B967E8345947

\section{Type-species}

Monocerichthys scheuchzei gen. et sp. nov. (by monotypy)

\section{Diagnosis}

As for the species (monospecific genus).

\section{Etymology}

From the Greek monokerôs, unicorn, and ichthys, fish.

Monocerichthys scheuchzeri gen. et sp. nov.

Figs 7-14

urn:1sid:zoobank.org:act:74512C09-6F58-4711-A028-93AFA9CB10FF

\section{Diagnosis}

Gladiopycnodontid with the prefrontal elongated in a short rostrum, outpacing only slightly the lower jaw level. Prefrontal with a spiny anterior tip. Vomer bearing small rounded molariform teeth irregularly ranged. Frontal short, narrow and with a weakly developed median protuberance. Dermosupraoccipital, parietal and dermopterotic longer than deep and articulated with a large supratemporal. Long nuchal horn with a broad basis, a very spiny posterior border and resting on the dermosupraoccipital, the supratemporal and the posttemporal. Orbitosphenoid articulated with the mesethmoid. Well developed triangular dermosphenotic. Premaxilla long, broad, toothless and sutured by its dorsal margin to the prefrontal. Large, toothless and triangular shaped maxilla. Small lower jaw. Hypertrophied trapezoid preopercle covering a great part of the cheek. Small opercle with a rounded dorsal border and an acuminate ventral tip. Exposed part of the hyomandibula-dermohyomandibula considerably smaller than the preopercle. Very large pectoral girdle closely associated to the skull and forming a sort of cephalothorax. Posttemporal articulated with the supratemporal. Hypertrophied hypercleithrum. Strongly hypertrophied cleithrum with a long and broad ventral branch and a large posterior ventral process. Long pectoral spine articulated on the cleithrum. 17 neural spines, all fused to their neural arches, before the epichordal series. Neural and haemal spines short and broad. Postcoelomic bone obliquely oriented. Short dorsal fin located in the middle of the back, with 13 pterygiophores, 1 small spiny ray and 12 segmented rays. Very short anal fin. Caudal fin with a convex posterior margin and with 17 principal rays, 6 dorsal and 7 ventral procurrent rays. Body entirely covered with very small flake-like scales. No dorsal ridge scutes. One large postcloacal scute below the postcoelomic bone.

\section{Etymology}

The species name of this new gladiopycnodontid fossil fish is dedicated to Johann Jacob Scheuchzer (1672-1733), the Swiss physician who was the first to illustrate a Lebanese fossil fish in his book Piscium Queralae et Vindiciae (1708) [cf. Gayet et al. 2012: 10].

\section{Holotype and unique specimen}

Sample CLC S-413a, b, the two faces of a complete specimen (Figs 7-8). Total length: $102 \mathrm{~mm}$.

\section{Formation and locality}

Marine Late Cenomanian, Haqel, Lebanon. 


\section{Holotype morphometric data}

The morphometric data are given in \% of the holotype standard length $(87 \mathrm{~mm})$.

Length of the head (opercle included)

$37.8 \%$

Length of the cephalo-thorax (cleithrum included)

$66.7 \%$

Depth of the head (with the nuchal horn)

$37.3 \%$

Depth of the head (without the nuchal horn)

$64.7 \%$
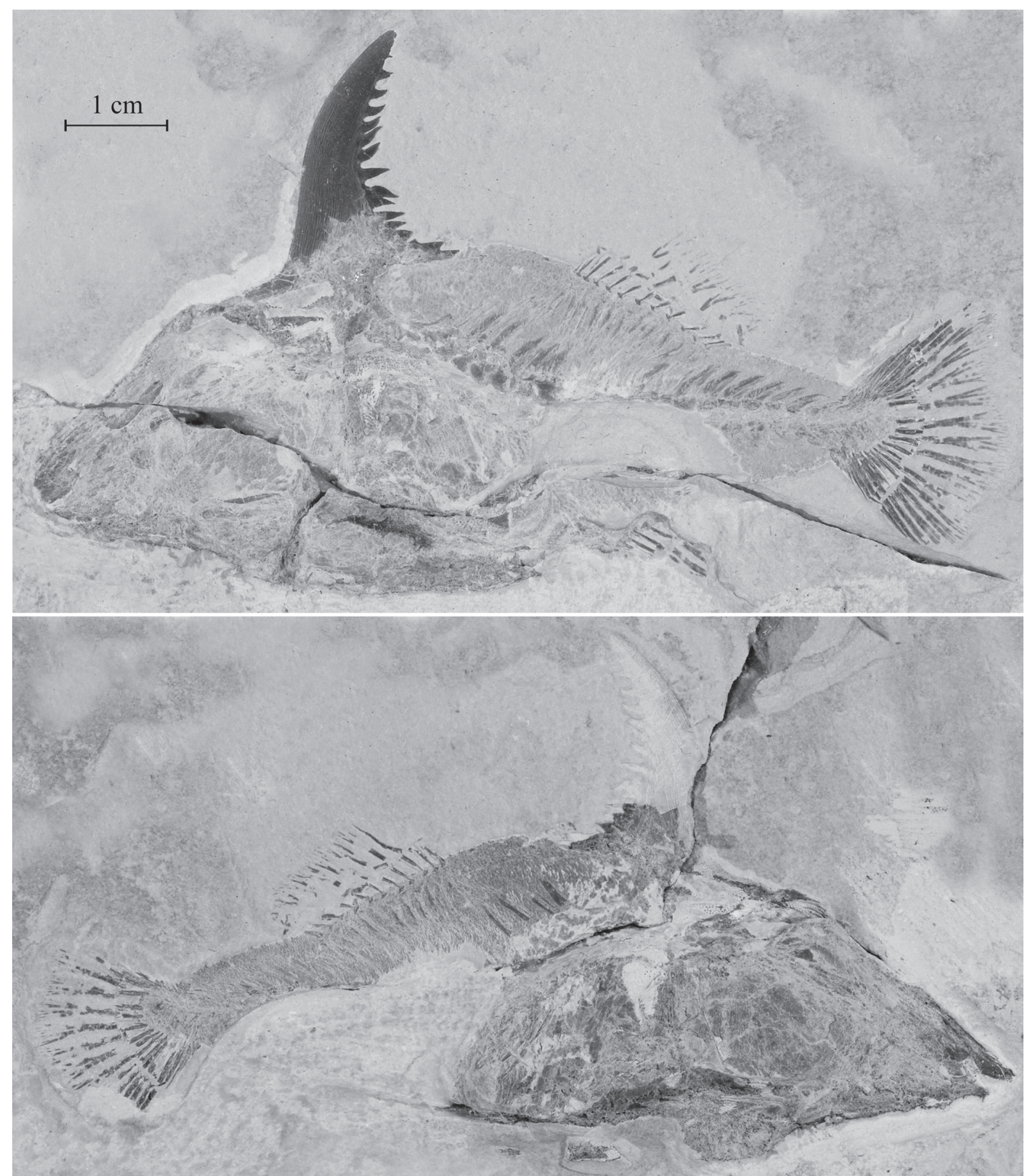

Fig. 7. Monocerichthys scheuchzeri gen. et sp. nov. Holotype CLC S-413a (above) and b (below). 
Maximum depth of the body (just behind the nuchal horn) $39.4 \%$

Length of the pectoral spine $19.9 \%$

Predorsal length $65.6 \%$

Basal length of the dorsal fin $18.2 \%$

Preanal length $72.6 \%$

Basal length of the anal fin $10.0 \%$

Depth of the caudal peduncle $9.5 \%$

\section{Osteology}

\section{The skull (Figs 9-10)}

The dermal bones of the skull are covered with small tubercles, but this ornamentation is not strongly pronounced.

The head is large, longer than high and triangular in shape. The snout is elongated in a short rostrum formed by the long and broad prefrontal and by the long toothless premaxilla. The anterior tip of the prefrontal is spiny. The rostrum outpaces only slightly the lower jaw level. The anterior region of the long mesethmoid and the vomer are hidden by the prefrontal and the premaxilla. However, the most anterior part of the premaxilla is broken on face CLC S-413b and a part of the vomer is visible. The bone bears very small, rounded molariform teeth, irregularly ranged.

The frontal is short, rather narrow and practically not curved. It extends anteriorly beyond the orbit level and exhibits a weakly developed median protuberance located just before the orbit, but there is no frontal horn. The posterior region of the skull roof is formed by the dermosupraoccipital, and the paired parietals and dermopterotics. These bones are rather small and longer than deep. There is no temporal fenestra. A large supratemporal is sutured with the posterior margin of the dermosupraoccipital, the parietal and the dermopterotic. The autosphenotic is located below the dermopterotic. A long and strong pointed

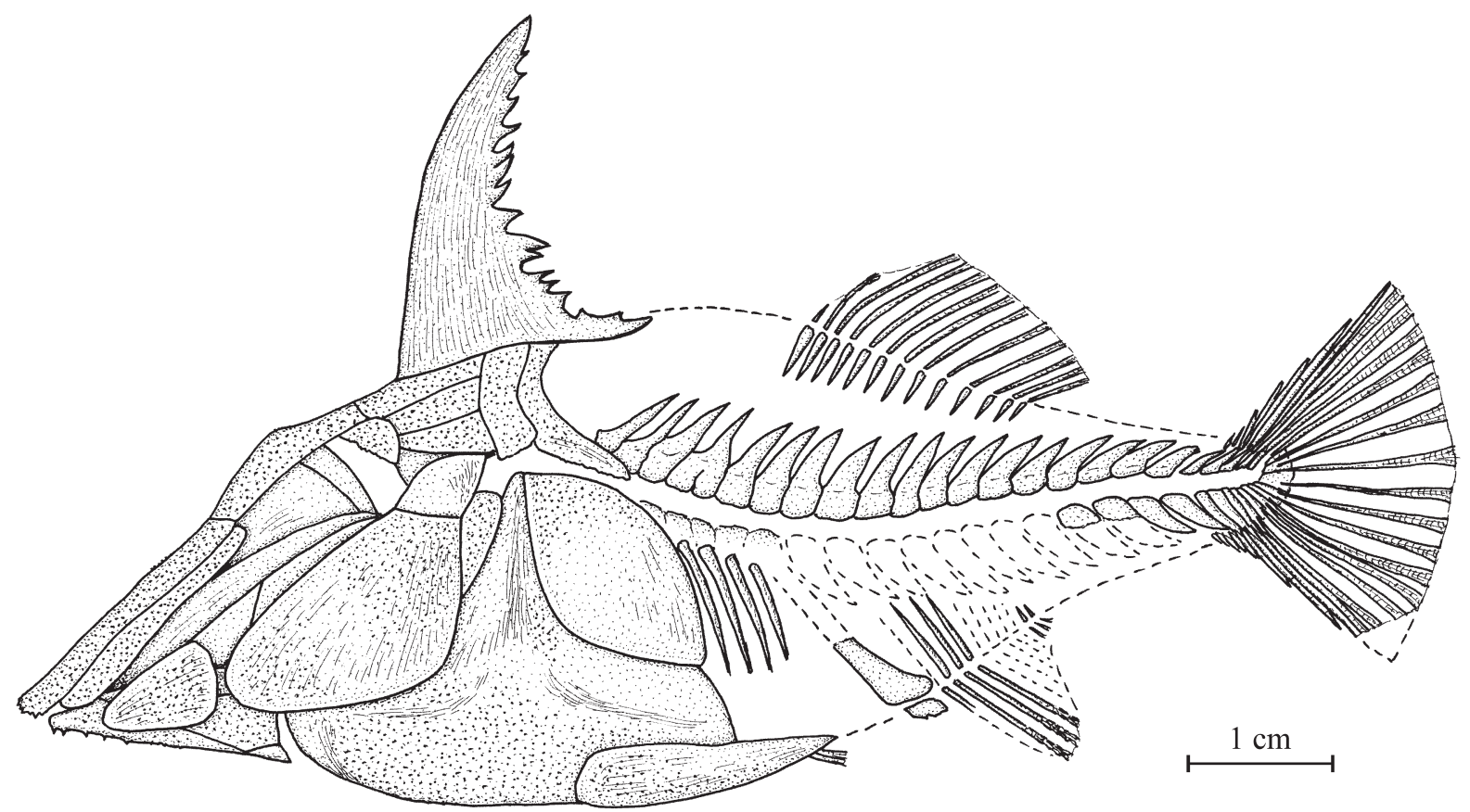

Fig. 8. Monocerichthys scheuchzeri gen. et sp. nov. General reconstruction based on the two faces of holotype CLC S-413a, b. Body scales are omitted. 
nuchal horn with a series of large spines on its posterior border is resting on the dermosupraoccipital, the supratemporal and also the posttemporal. The very broad basis of that horn extends on the beginning of the back.

The parasphenoid is very long and toothless. The orbitosphenoid is pressed against the mesethmoid. The other endochondral bones of the braincase are not accessible.

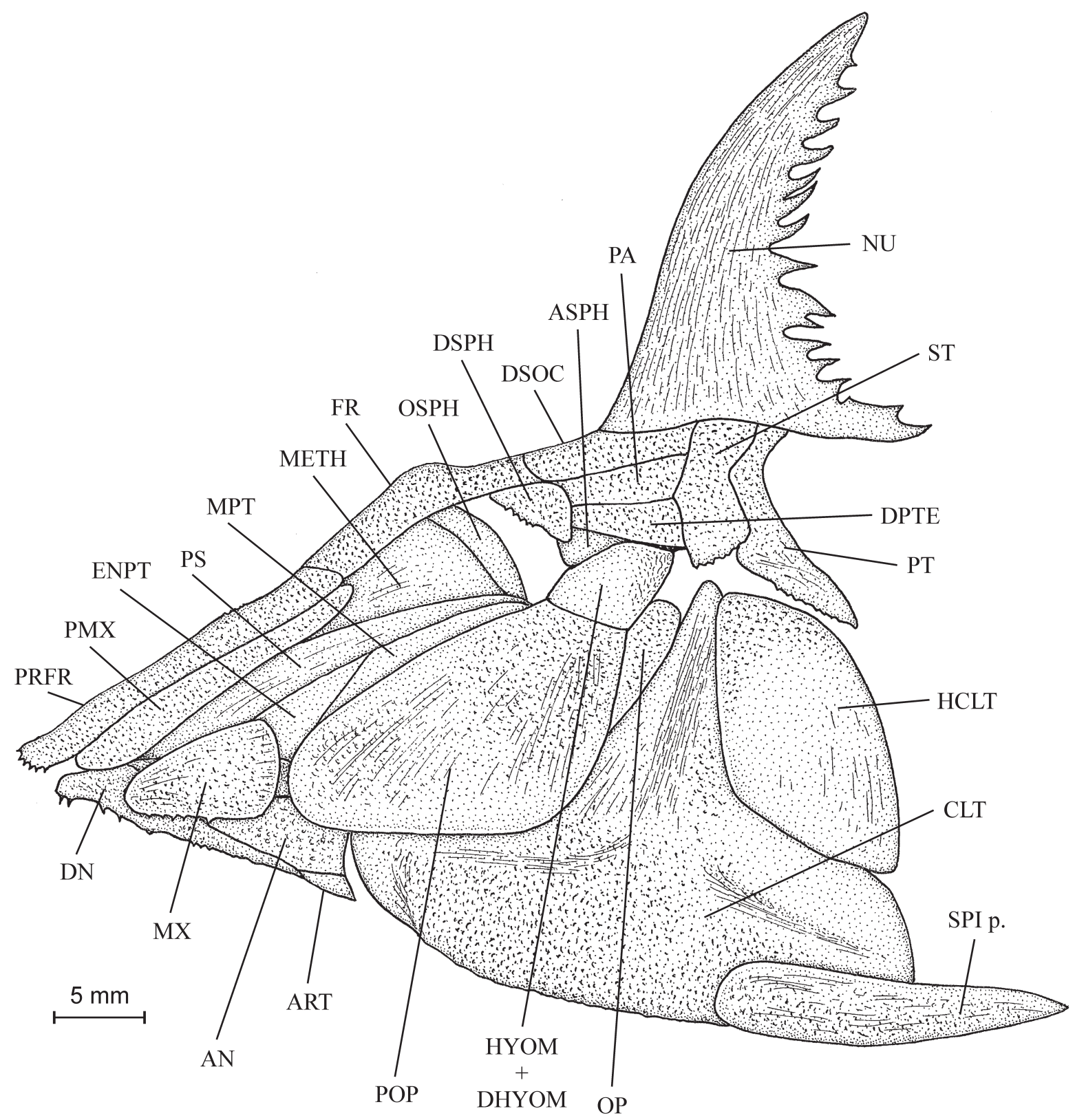

Fig. 9. Monocerichthys scheuchzeri gen. et sp. nov. Reconstruction of the skull and the pectoral girdle based on the two faces of holotype CLC S-413a, b. 


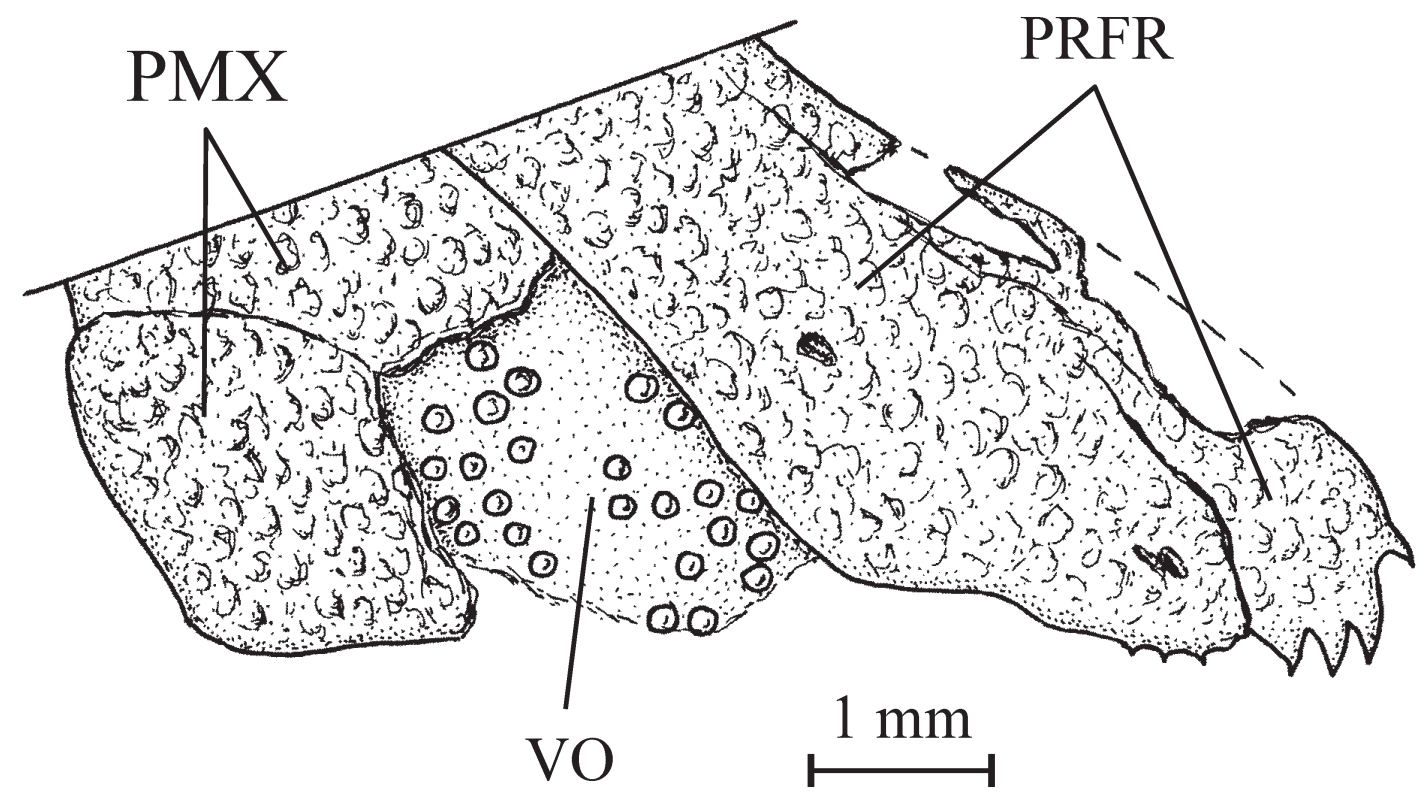

Fig. 10. Monocerichthys scheuchzeri gen. et sp. nov. The vomerian region of the skull in holotype CLC S-413b.

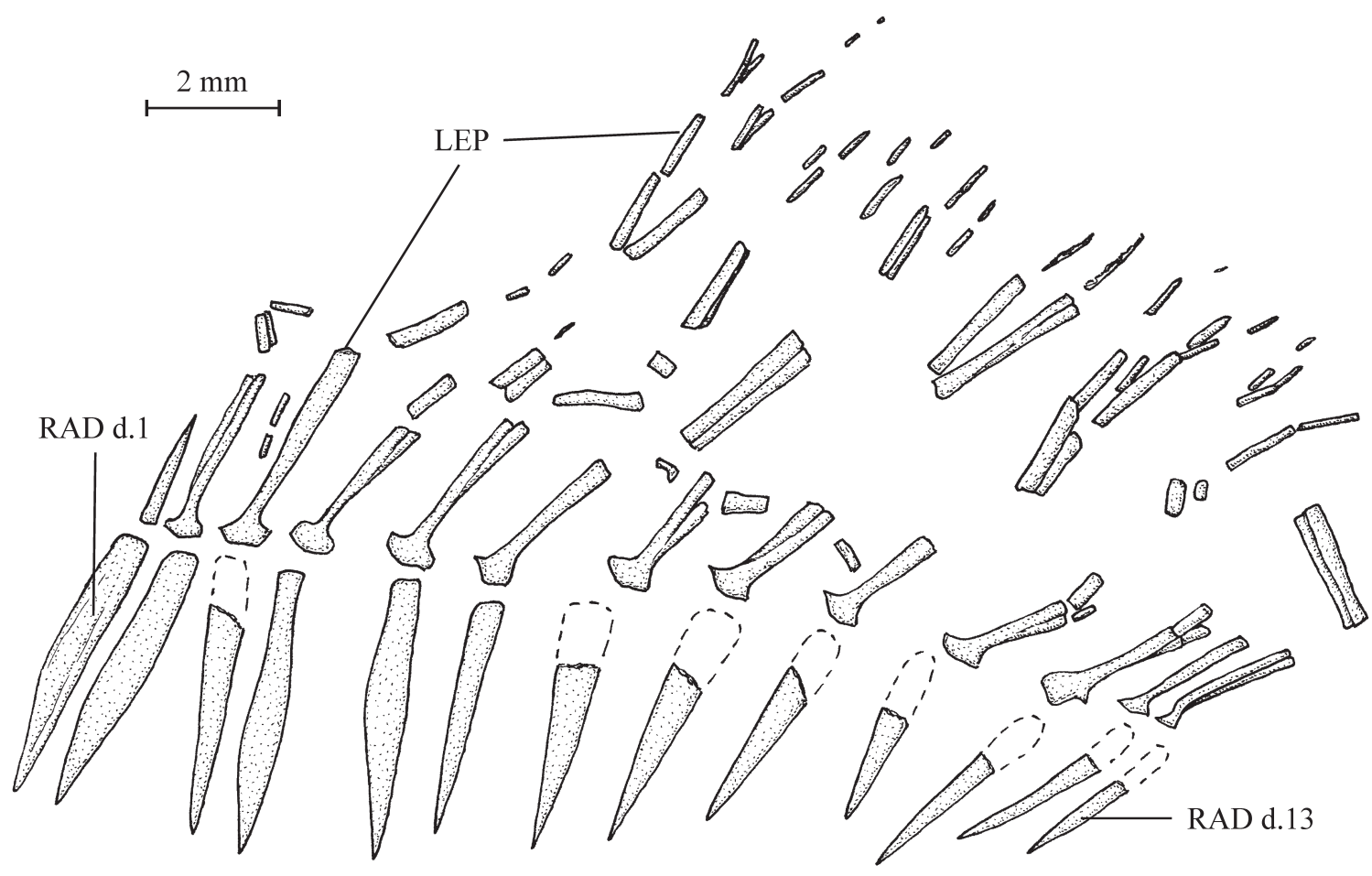

Fig. 11. Monocerichthys scheuchzeri gen. et sp. nov. The dorsal fin of holotype CLC S-413a. 
Small fragments of the metapterygoid and the entopterygoid are visible between the preopercle and the parasphenoid, but a great part of those two bones remains hidden by the preopercle in the same way as the quadrate and the symplectic.

The upper jaw contains a large, more or less triangular and toothless maxilla and a long, broad and toothless premaxilla that is articulated to the prefrontal by its upper margin. The lower jaw is triangular in shape and rather small. The dentary is reduced to its ventral branch. Its ventral margin is spiny. The teeth are not preserved. Other gladiopycnodontid genera have two teeth on the dentary. There is a large angular and a small articular. It is not possible to determine whether the prearticular was toothed or not or whether a marked coronoid process was present. The prearticular bears molariform teeth on its inner face in some other gladiopycnodontid fishes.

The orbit is small. A large triangular dermosphenotic is located below the frontal and before the parietal and the dermopterotic. No other orbital bone is preserved.

The exposed part of the hyomandibula-dermohyomandibula is important; however, it is much smaller than the hypertrophied trapezoid-shaped preopercle, that almost entirely covers the cheek. The opercle is a small bone, deeper than long, dorsally rounded and ventrally acuminate. The subopercle and the interopercle are absent, as in all pycnodontomorph fish.

The hyoid bar, the branchiostegal rays and the branchial skeleton are not visible.

\section{The girdles (Figs 8-9)}

The pectoral girdle is closely associated to the skull, both structures forming a sort of cephalo-thorax. The pectoral bones are ornamented with small tubercles. The posttemporal is a deep bone, narrow in its upper part but ventrally broader, that is sutured anteriorly to the supratemporal and dorsally to the nuchal horn. The hypercleithrum (= supracleithrum) is hypertrophied in a large, more or less ovoid plate. The

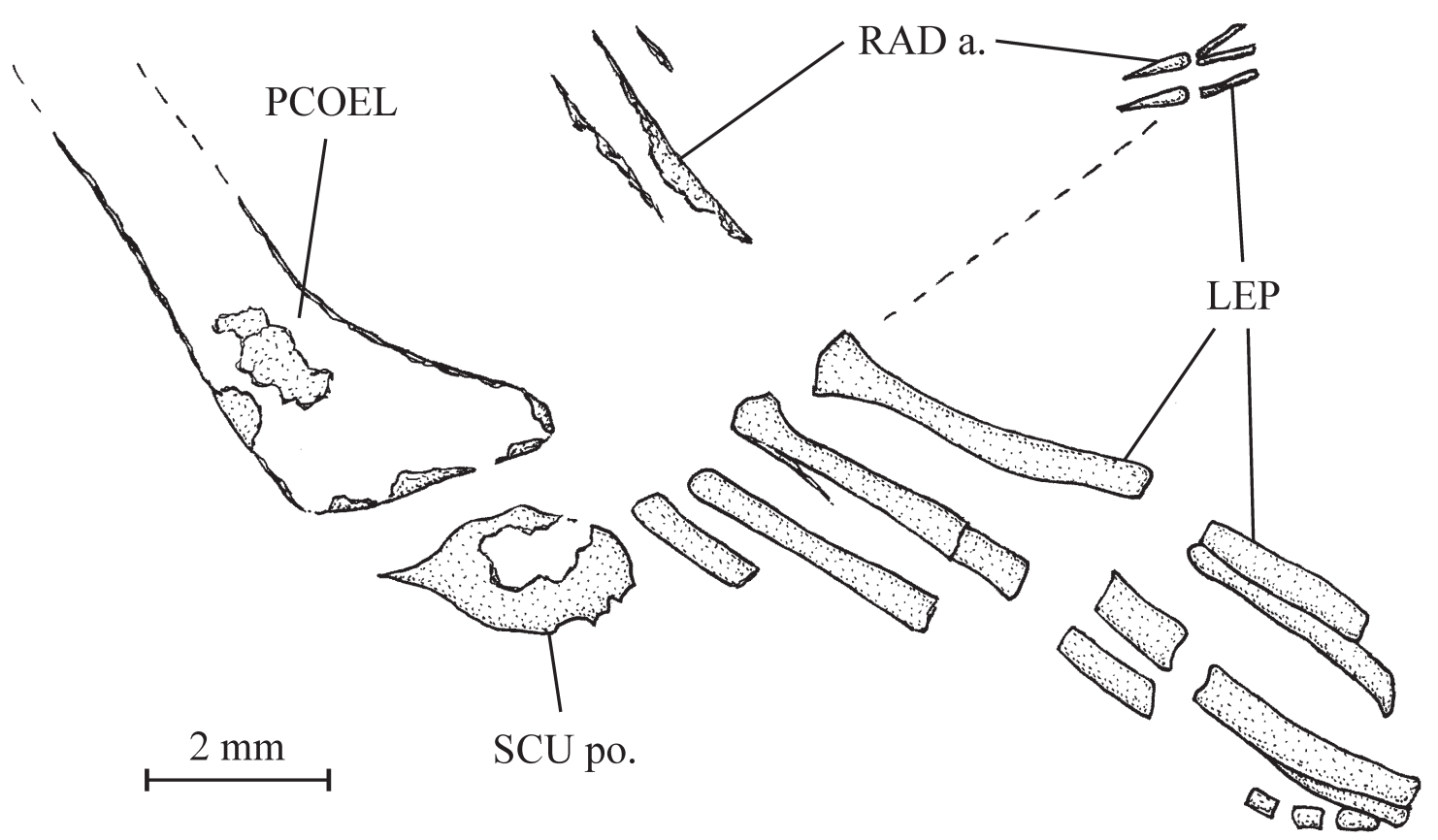

Fig. 12. Monocerichthys scheuchzeri gen. et sp. nov. The anal fin of holotype CLC S-413a. 
cleithrum is gigantic, with a well developed dorsal branch, a long and broad ventral branch and a very large posterior ventral process. The pectoral fin is replaced by a long strong spine. There is no soft ray.

No pelvic bones are visible, but small fragments of rays from the ventral fins are preserved just above the posterior point of the pectoral spine on face CLC S-413a.

\section{The axial skeleton (Fig. 8)}

The trunk is fusiform and not deep-bodied as usual in most pycnodontomorph fishes. The abdominal part of the axial skeleton progressively elevates and anteriorly reaches the orbit level. The vertebrae are constituted by the dorsal and ventral arcocentra only. The notochord is not completely surrounded by the arches. There are 17 neural spines before the epichordal series of the caudal skeleton. They are short, but rather broad. All those neural spines are fused to their neural arches. Non of them are autogenous. The first neural spine corresponds to the first ossified neural arch. The fourth neural spine is fused to two neural arches. That is probably an individual variation and not a specific character. A few badly preserved traces of the basiventrals from the abdominal region are visible, but the basiventrals of the

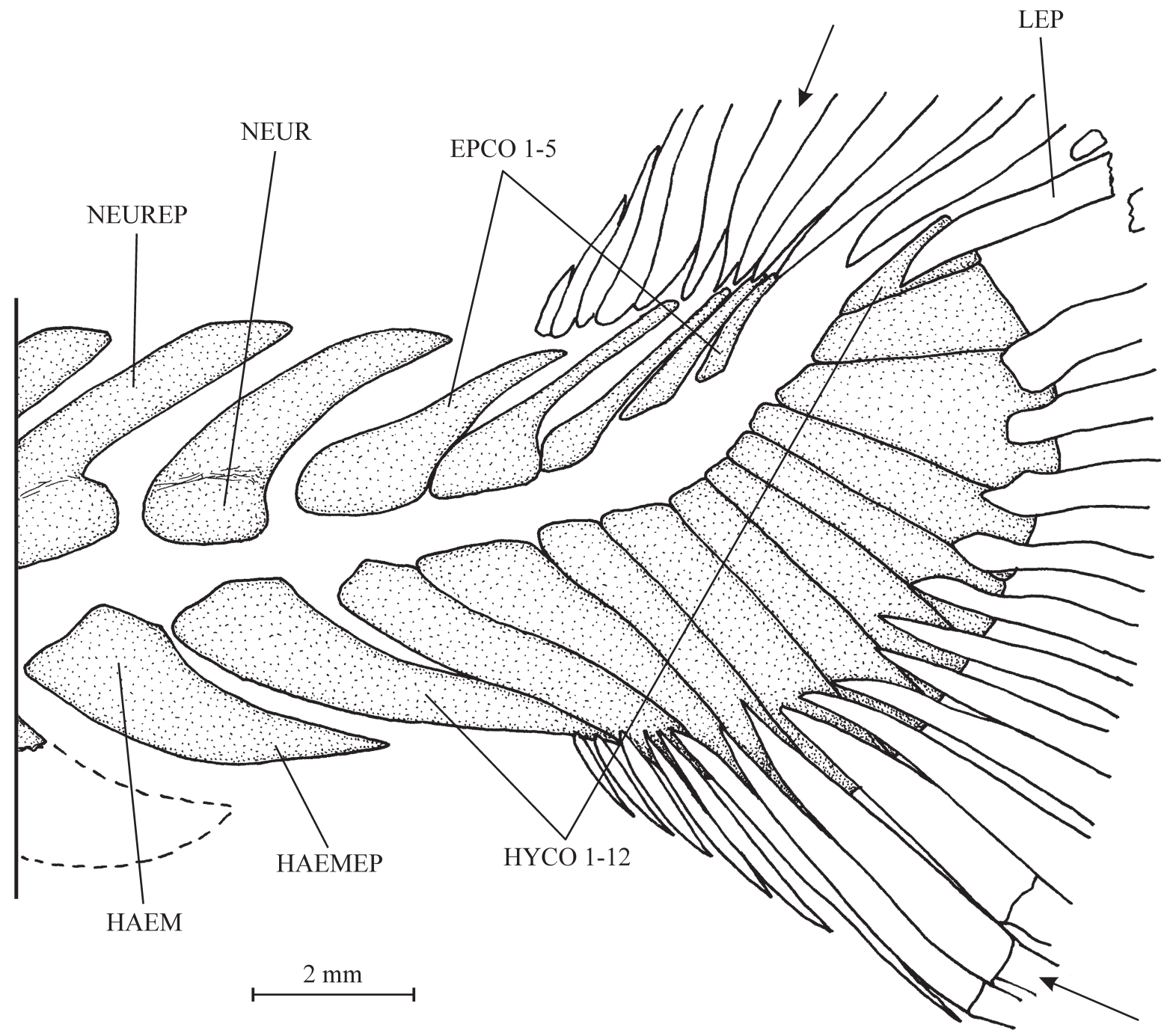

Fig. 13. Monocerichthys scheuchzeri gen. et sp. nov. Reconstruction of the caudal skeleton, based on the two faces of holotype CLC S-413a, b. 
caudal region and the haemal spines are lost, except the last ones near the tail. Four long and strong ribs are seen just behind the hypercleithrum on face CLC S- $413 \mathrm{~b}$. The few preserved haemal spines are short and broad, as the neural spines.

Only fragments of the most ventral part of the postcoelomic bone are preserved. The bone is well developed, obliquely oriented and with an enlarged lower extremity that is directed backwards.

\section{The dorsal and anal fins (Figs 8, 11-12)}

The dorsal fin is short but rather high and is located in the middle of the back. The fin begins with 1 small spiny ray, followed by 12 long segmented and branched rays. There are 13 pterygiophores, each of them bearing one ray.

The anal fin is partly preserved on face CLC S-413a but is completely missing on face $b$. The fin is still shorter than the dorsal one and is also located on the middle of the body, far from the tail. Fragments of three pterygiophores and of four rays are visible in the beginning of the fin, just behind the postcoelomic bone. Two very small pterygiophores and three very small rays are visible at the posterior extremity of the fin.

\section{The caudal skeleton (Fig. 13)}

A caudal peduncle is present. The caudal skeleton is not very well preserved, but the two faces CLC $\mathrm{S}-413 \mathrm{a}$ and $\mathrm{b}$ complete each other and allow to entirely reconstruct the whole structure. The caudal fin is dorsally supported by 5 epichordals and ventrally by 12 hypochordals. The tenth and eleventh hypochordals are moderately broadened, but there is no real hypertrophy. The hypochordal series begins one vertebral segment before the epichordal series. No urodermal is visible, but this is probably

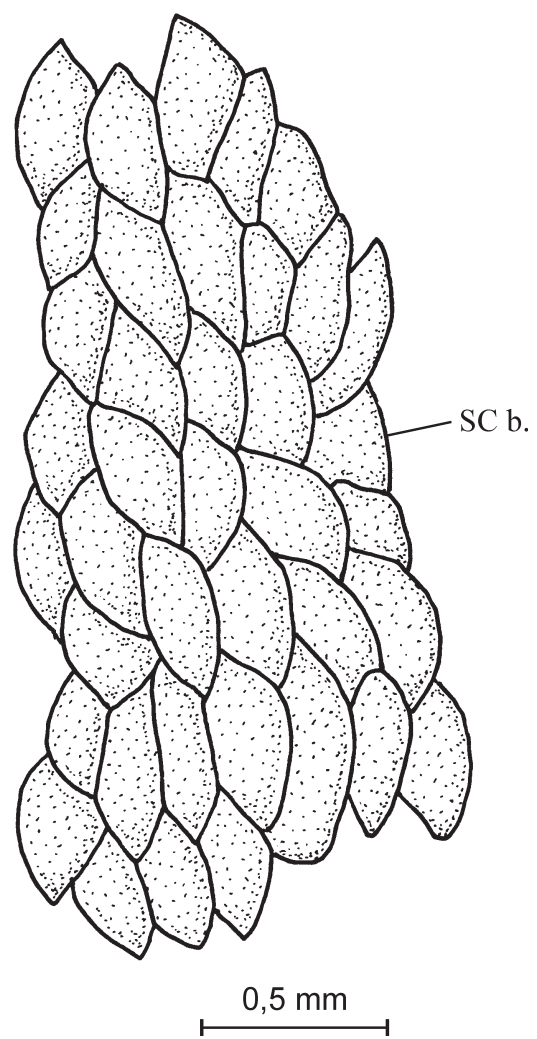

Fig. 14. Monocerichthys scheuchzeri gen. et sp. nov. Body scales from holotype CLC S-413a, from the dorsal region near the tail. 
TAVERNE L. \& CAPASSO L., Gladiopycnodontidae fam. nov. (Pisces) from the Cretaceous of Lebanon

a taphonomic artefact. Indeed, a well developed urodermal does exist in some gladiopycnodontid fishes more specialized than M. scheuchzeri gen. et sp. nov. (pers. obs.).

The caudal fin is not very large and has a convex posterior margin (Poyato-Ariza \& Wenz 2002: fig. 36B). There are 17 principal rays. The most dorsal and ventral principal rays are segmented but unbranched. The other principal rays are segmented and branched. There are 6 dorsal and 7 ventral procurrent rays.

6. Squamation (Fig. 14)

The body is entirely covered with very small, flake-like scales that are imbricated one into another. Rather similar scales exist in Gladiopycnodus karami gen. et sp. nov., but they are deeper and much larger. There are no peculiar scales or scutes, either on the dorsal ridge or on the ventral keel.

A large irregular postcloacal scute is present just below the postcoelomic bone.

Genus Rostropycnodus gen. nov. urn:1sid:zoobank.org:act:66711DD0-8E43-4531-B64A-21071FE34C98

\section{Type-species}

Rostropycnodus gayeti gen. et sp. nov. (by monotypy)

\section{Diagnosis}

As for the species (monospecific genus).

\section{Etymology}

From the Latin rostrum, rostrum. The generic name Pycnodus is added.

Rostropycnodus gayeti gen. et sp. nov.

Figs 15-21

urn:1sid:zoobank.org:act:89707CF2-AF8E-450E-8D6F-16A0B02EDE93

\section{Diagnosis}

Gladiopycnodontid with a very long snout, forming a rostrum anteriorly outpacing the lower jaw level (Fig. 18). Anterior tip of the rostrum formed by both the prefrontal and the premaxilla. Anterior extremity of the prefrontal bearing four small spines. Frontal bearing one long pointed horn. Dermosupraoccipital forming a nuchal process. Small lower jaw. Preopercle much larger than the exposed part of the hyomandibula-dermohyomandibula. Posttemporal articulated with the nuchal process. Hypertrophied cleithrum with a long and broad ventral branch. Short and broad pectoral spine. Two large postcleithra. Nuchal horn absent. 17 neural spines and 17 haemal spines before the epichordal and hypochordal series. Dorsal fin with 6 pterygiophores. Anal fin with a long and strong initial spine and 4 short soft rays. Caudal skeleton with 6 epichordal and 7 hypochordal elements. Last three hypochordal elements moderately broadened. Caudal fin with 21 rays and a convex posterior margin. Body entirely covered by large, tuberculated scales with a spiny anterior border.

\section{Etymology}

The species name of the new gladiopycnodontid is dedicated to Mireille Gayet (Lyon), the well known French palaeontologist, who has greatly improved our knowledge of the Late Cretaceous ichthyofauna of Lebanon. 


\section{Material examined}

\section{Holotype}

Sample CLC S-608a, b, the two faces of a nearly complete specimen (Fig. 15). The tip of the rostrum and the caudal fin are missing. Total length: $47.3 \mathrm{~mm}$.
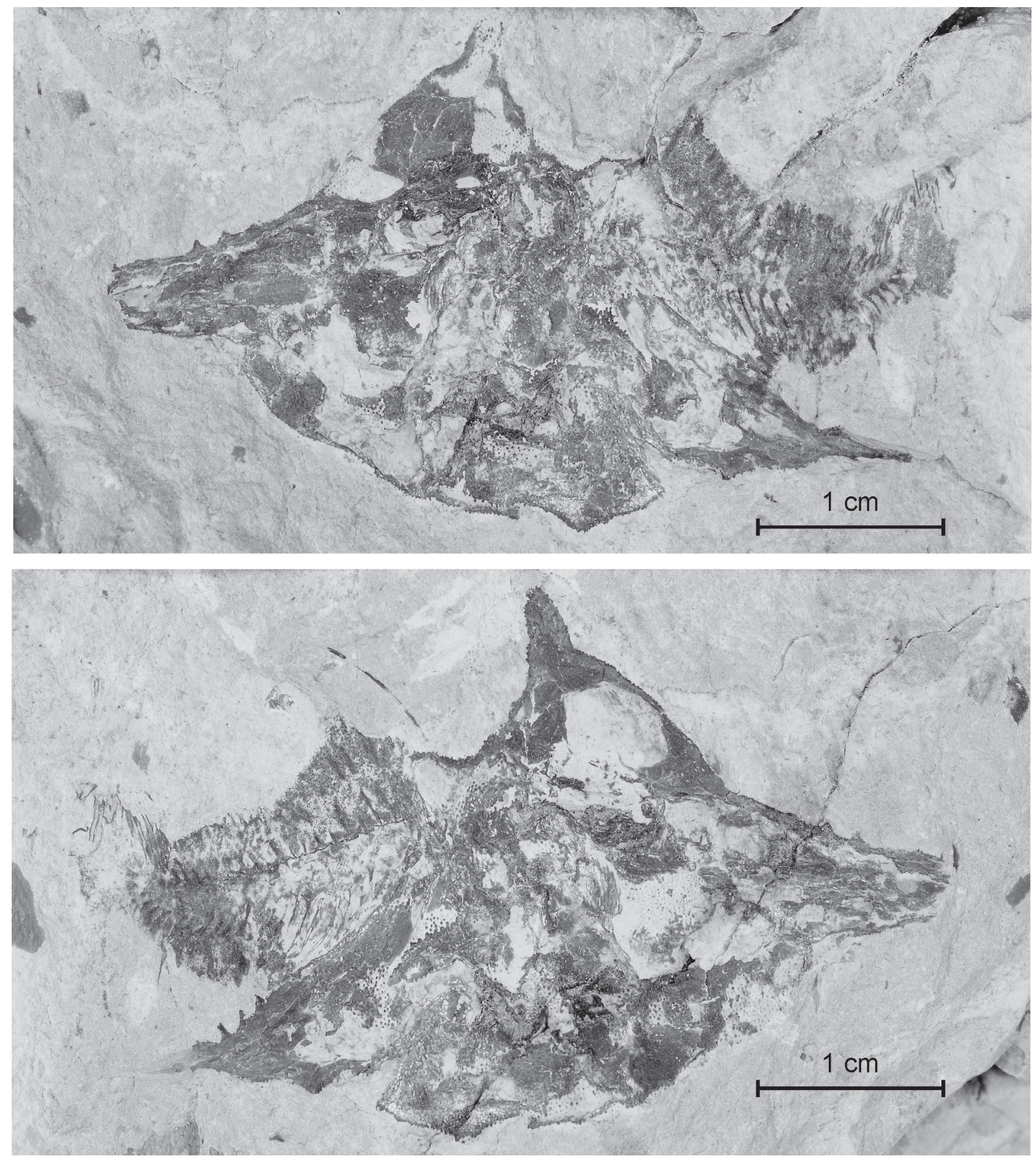

Fig. 15. Rostropycnodus gayeti gen. et sp. nov. Holotype CLC S-608a (above) and 608b (below). 
TAVERNE L. \& CAPASSO L., Gladiopycnodontidae fam. nov. (Pisces) from the Cretaceous of Lebanon

\section{Paratypes}

Sample CLC S-337, a complete specimen (Fig.16). The body and the tail are severely crushed. Total length: $59.8 \mathrm{~mm}$.

Sample CLC S-595, a nearly complete specimen (Fig.17). The tip of the rostrum is missing. Total length: $58.6 \mathrm{~mm}$.

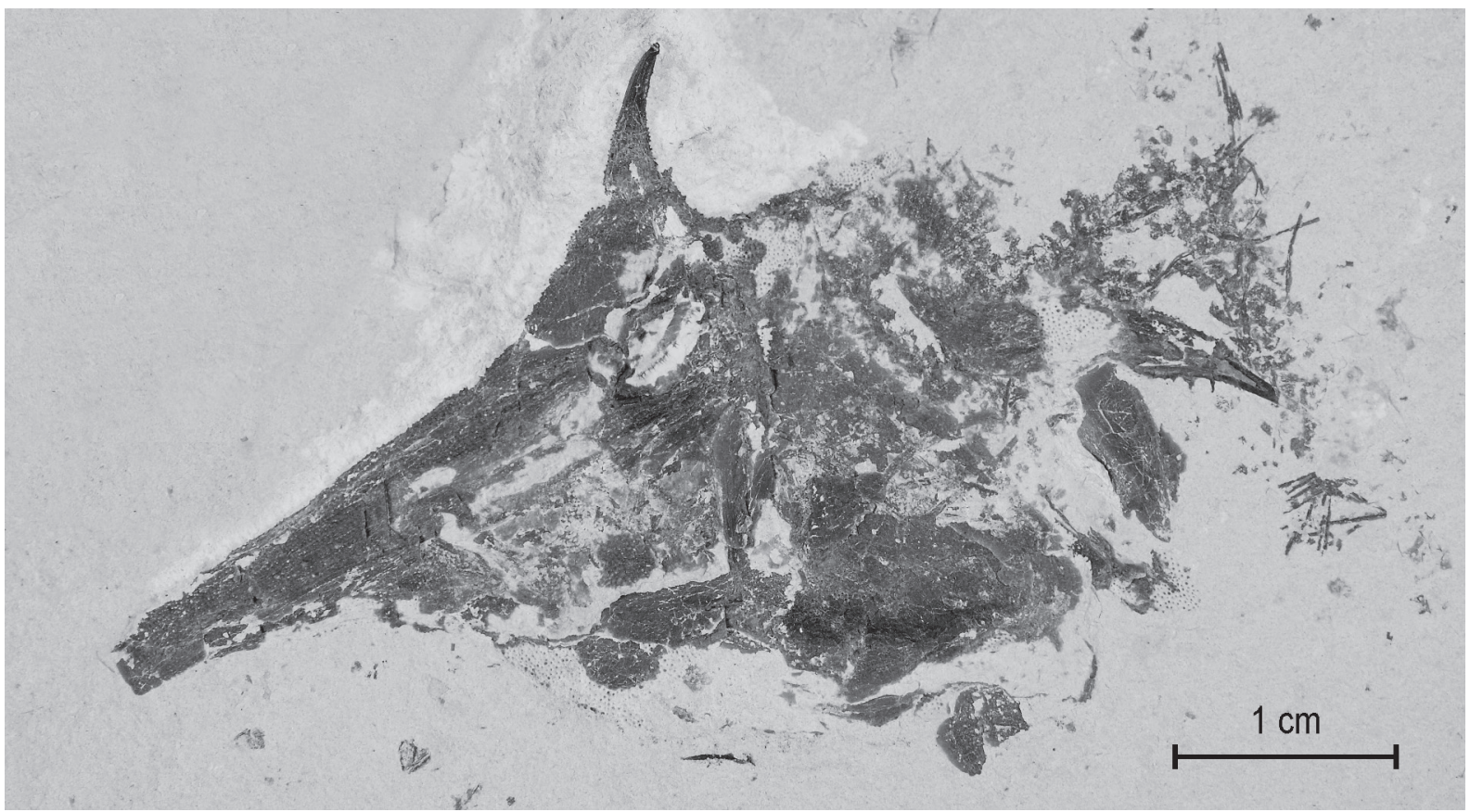

Fig. 16. Rostropycnodus gayeti gen. et sp. nov. Paratype CLC S-337.

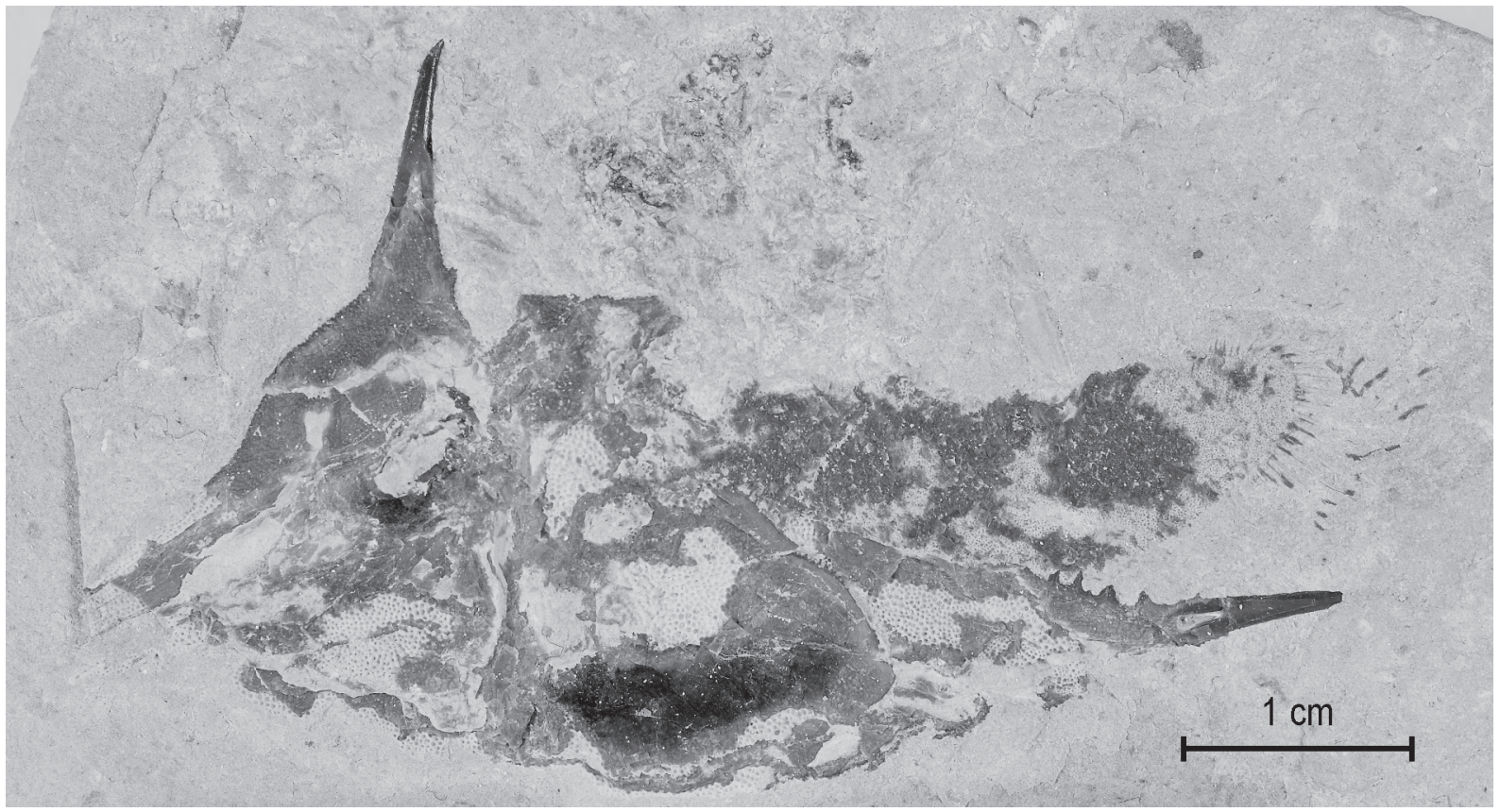

Fig. 17. Rostropycnodus gayeti gen. et sp. nov. Paratype CLC S-595. 


\section{Formation and locality}

Marine Upper Cenomanian, Haqel, Lebanon.

\section{Holotype morphometric data}

Due to the incompleteness of the available specimens, no accurate morphological data can be provided and the reconstruction is therefore composite.

\section{Osteology}

\section{The skull (Fig. 19)}

The head, rostrum and opercular series included, is twice as long as the body. The dermal bones of the skull are ornamented with a few thin ridges and many tubercles.

The snout is elongated, forming a long rostrum that is, however, shorter than in Gladiopycnodus karami gen. et sp. nov. The preorbital length, rostrum included, represents $59.5 \%$ of the total length of the skull. The rostrum consists of the prefrontals, the premaxillae, the mesethmoid and the parasphenoid. Only the most posterior parts of the mesethmoid and of the parasphenoid are visible. Both the prefrontal and the premaxilla form the tip of the rostrum. The long and broad prefrontal bears four small spines on its anterior tip as seen on sample CLC S-337. The upper margin of the prefrontal is ornamented with small spines. The vomer remains hidden by the premaxilla. A vomer with very small molariform teeth is present in the family, as shown in some other gladiopycnodontid genera.

The frontal and the dermosupraoccipital are the main bones of the skull roof. The frontal is short but broad. Anteriorly, it does not go beyond the orbit. The frontal bears a long pointed horn with a large basis and of which the anterior and posterior borders are spiny. The dermosupraoccipital is enlarged and forms a long and broad nuchal process. The autosphenotic, parietal and dermopterotic are rather small bones. The parietal does not bear a brush-like process. The large supratemporal is pressed against the dermosupraoccipital.

The parasphenoid is long and toothless. A well developed orbitosphenoid is articulated on the rear of the mesethmoid. The other endocranial bones of the braincase are hidden by the hyomandibuladermohyomandibula, the opercle and the hypercleithrum.

The toothless upper jaw is a part of the rostrum. The premaxilla is very long and rather narrow but, however, a little broader anteriorly than posteriorly. It is located under the prefrontal and is sutured with it all along its upper margin. The maxilla is small, considerably shorter than the premaxilla, lance headshaped and posteriorly located.

The lower jaw is small, triangular in shape and, by far, does not reach the anterior extremity of the rostrum. The short dentary bone, well visible on specimen CLC S-608, is reduced to its ventral branch. The teeth are not preserved. The other bones of the mandible are too crushed to allow adequate description.

The bones of the palatoquadrate arch are hidden by the preopercle.

A large dermosphenotic is the only part preserved of the infraorbital series.

The exposed part of the hyomandibula-dermohyomandibula is much smaller than the large preopercle that is, however, not as hypertrophied as in Gladiopycnodus karami gen. et sp. nov. The preopercle is separated from the lower margin of the fish by the cleithrum, another difference from G. karami gen. et sp. nov.. The small opercle is a deep ovoid bone with an acuminate ventral extremity. The hyoid bar 
TAVERNE L. \& CAPASSO L., Gladiopycnodontidae fam. nov. (Pisces) from the Cretaceous of Lebanon

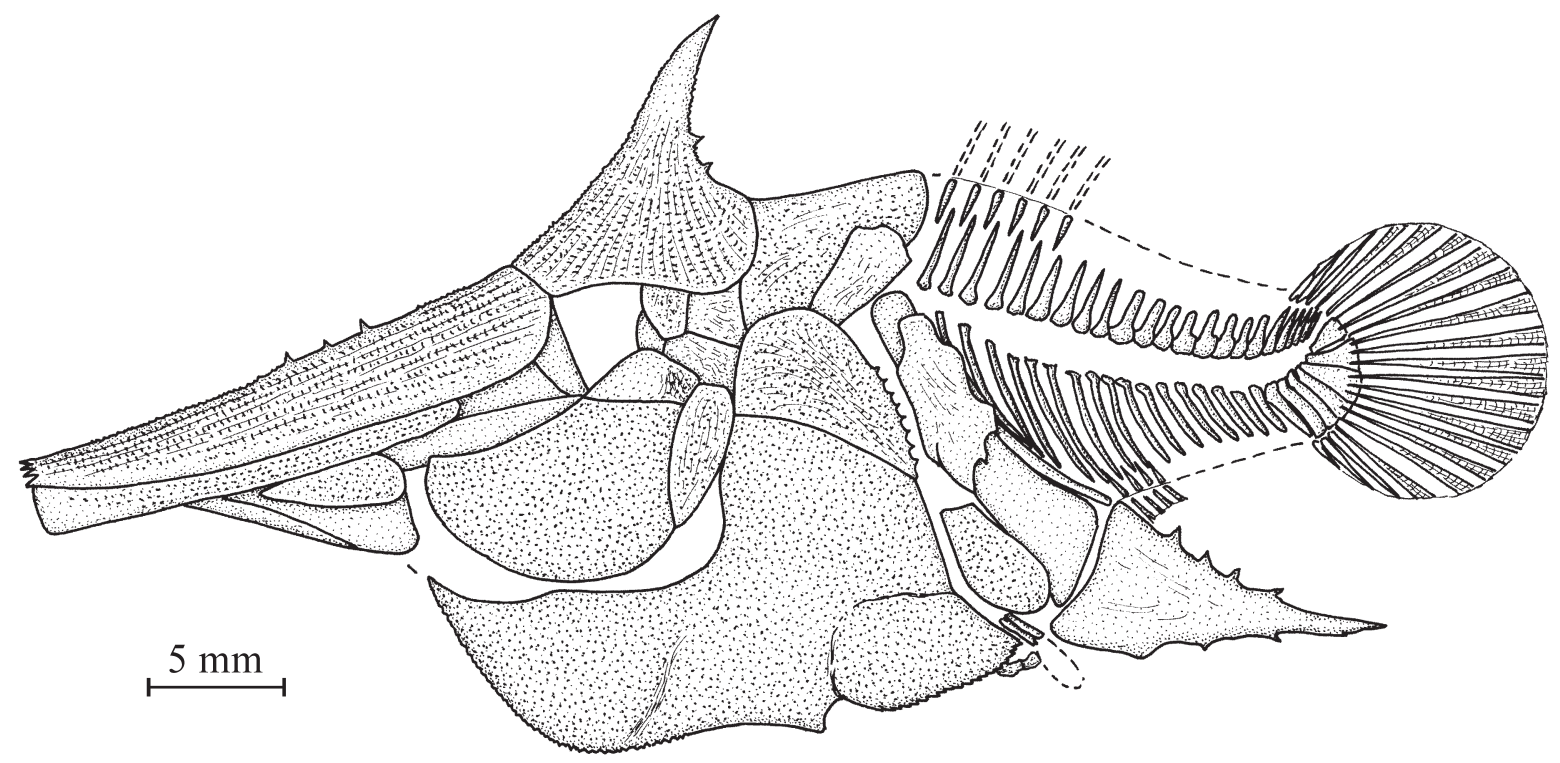

Fig. 18. Rostropycnodus gayeti gen. et sp. nov., paratype CLC S-337. Reconstruction based on the three specimens. Body scales omitted.

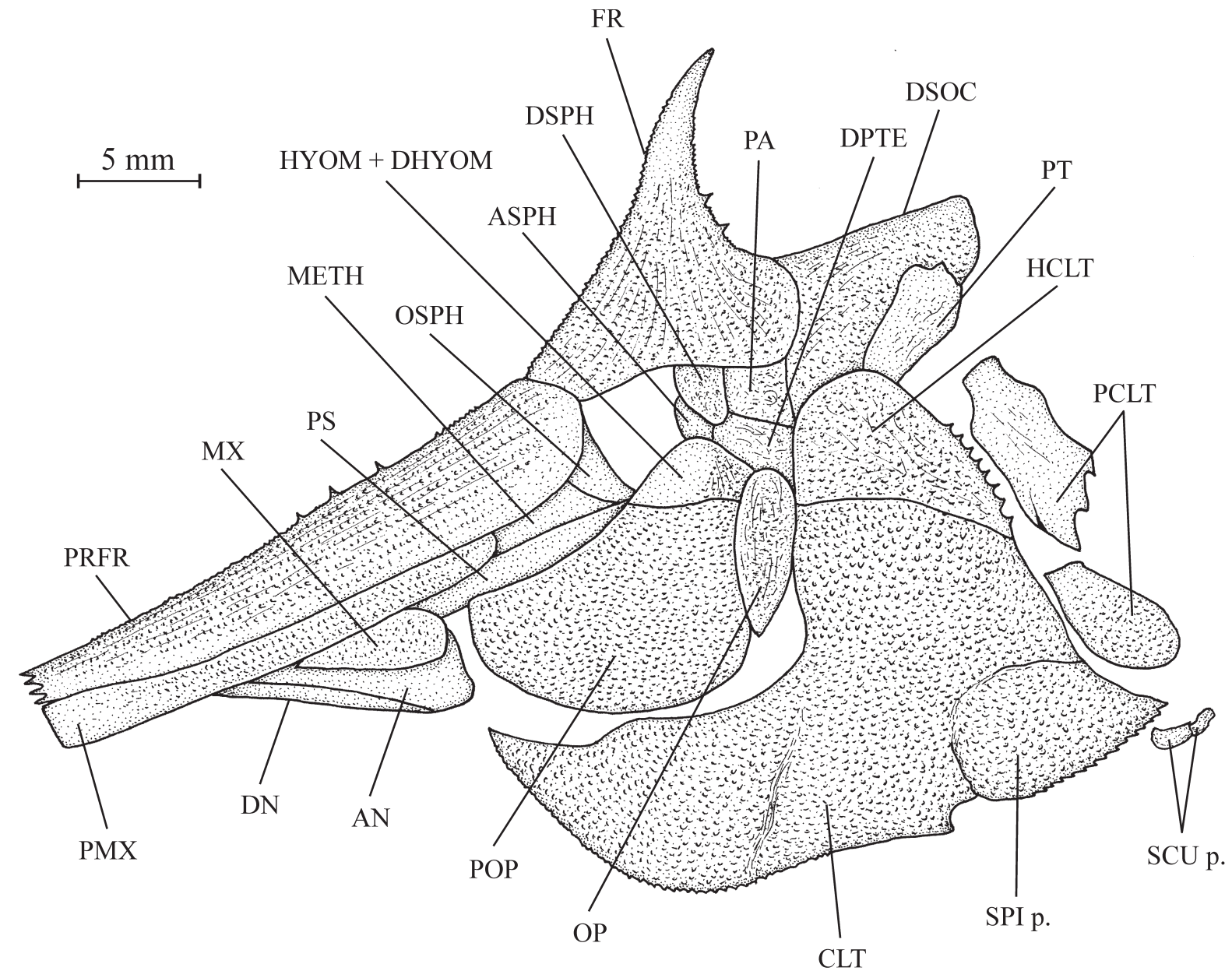

Fig. 19. Rostropycnodus gayeti gen. et sp. nov., paratype CLC S-337 Reconstruction of the skull based on the three specimens. 
and the branchiostegal rays are not visible. A fragment of a branchial bone and a few short nail-shaped branchiospines are preserved in the orbit of specimen S-337.

\section{The girdles (Figs 18-19)}

The massive pectoral girdle is intimately associated with the skull, forming a sort of cephalo-thorax. The posttemporal is well developed and located just behind the hypercleithrum. The hypercleithrum (= supracleithrum) is a large triangular bone with some spines on its posterior border. The cleithrum is really gigantic, with a very broad dorsal branch and a very long, broad and pointed ventral branch reaching the lower jaw level. There are two large postcleithra well visible on sample CLC S-337 and located behind the cleithrum. The pectoral fin is replaced by a short but very broad spine that is partially fused with the cleithrum.

Two small pelvic bones are preserved between the cleithrum and the post-coelomic bone on specimen CLC S-595, but the fin rays are lost.

\section{The axial skeleton (Fig. 18)}

The body is fusiform. Holotype CLC S-608a, b shows a complete vertebral column. The notochord is incompletely surrounded by the neural and haemal arches, which are reduced. The neural and haemal spines are well developed. There are 17 neural spines before the epichordal series and 17 haemal spines before the hypochordal series. The first ten neural spines are thin. The seven other spines are shorter but also broader. The first three haemal spines are rather short. Their length progressively increases from the fourth to sixth one and then decreases from the seventh to the seventeenth. The neural and haemal spines are not interlocked together by interdigitating sutures. The presence of ribs is uncertain, the situs viscerum being hidden by the gigantic cleithrum.

The post-coelomic bone is moderately long, robust, extremely broad and backwardly curved. Dorsally it reaches the vertebral axis and ventrally the inferior border of the fish.

\section{The dorsal and anal fins (Fig. 20)}

The dorsal fin is short. Holotype CLC S-608b shows 6 dorsal pterygiophores, largely separated from each other. The dorsal rays are lost but, considering the spacing between the pterygiophores, they surely formed a series of isolated finlets as in Gladiopycnodus karami gen. et sp. nov.

The anal fin begins with a large and strong spine. This spine has spiny dorsal and ventral margins, an acuminate posterior tip and a very broad basis articulated on the post-coelomic bone and the first anal pterygiophore, which is much longer than the following ones. The pointed tip of the spine reaches the level of the tail but does not outpace the caudal fin as in G. karami gen. et sp. nov. Four other small anal pterygiophores, bearing four short rays, are visible on holotype CLC S-608a.

\section{The caudal skeleton (Fig. 21A)}

The caudal skeleton is rather well preserved on holotype CLC S-608a, b. There are 6 epichordal elements and 7 hypochordal elements. The last three hypochordal pieces are moderately broadened. No urodermal is visible.

Paratype CLC S-595 possesses a more or less complete caudal fin, but essentially preserved as a print. There are 21 rays, but it is not possible to distinguish the procurrent from the principal rays. The fin has a convex distal border (Poyato-Ariza \& Wenz 2002: fig. 36 B).

\section{Squamation (Fig. 21B)}

The body is entirely covered by large deep scales that are imbricated. Their entire surface is ornamented with well developed tubercles and their anterior border is often irregularly spiny, as clearly seen on 


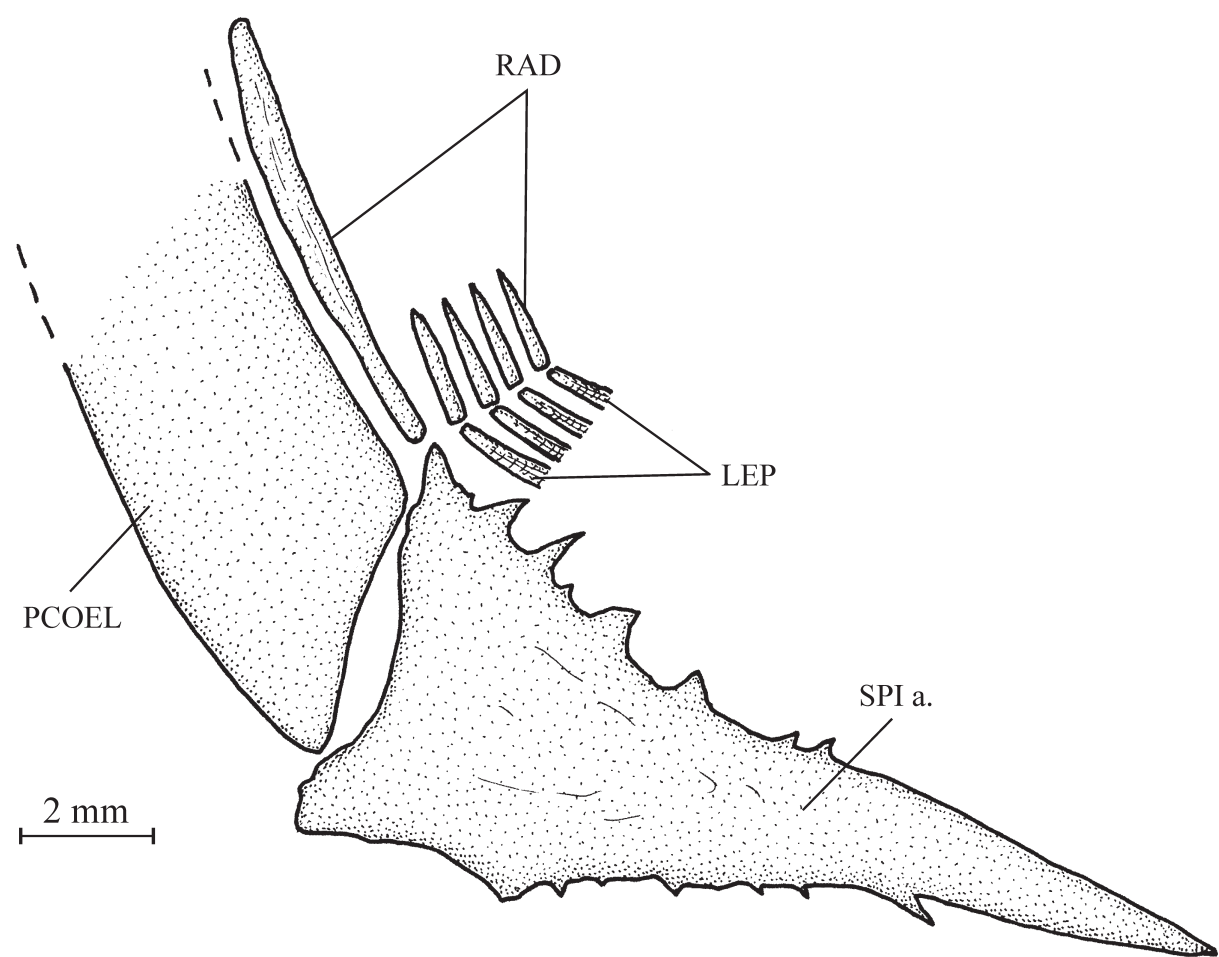

Fig. 20. Rostropycnodus gayeti gen. et sp. nov. The pelvic and anal region of holotype CLC S-608 (above) and of paratype CLC S-595 (below).
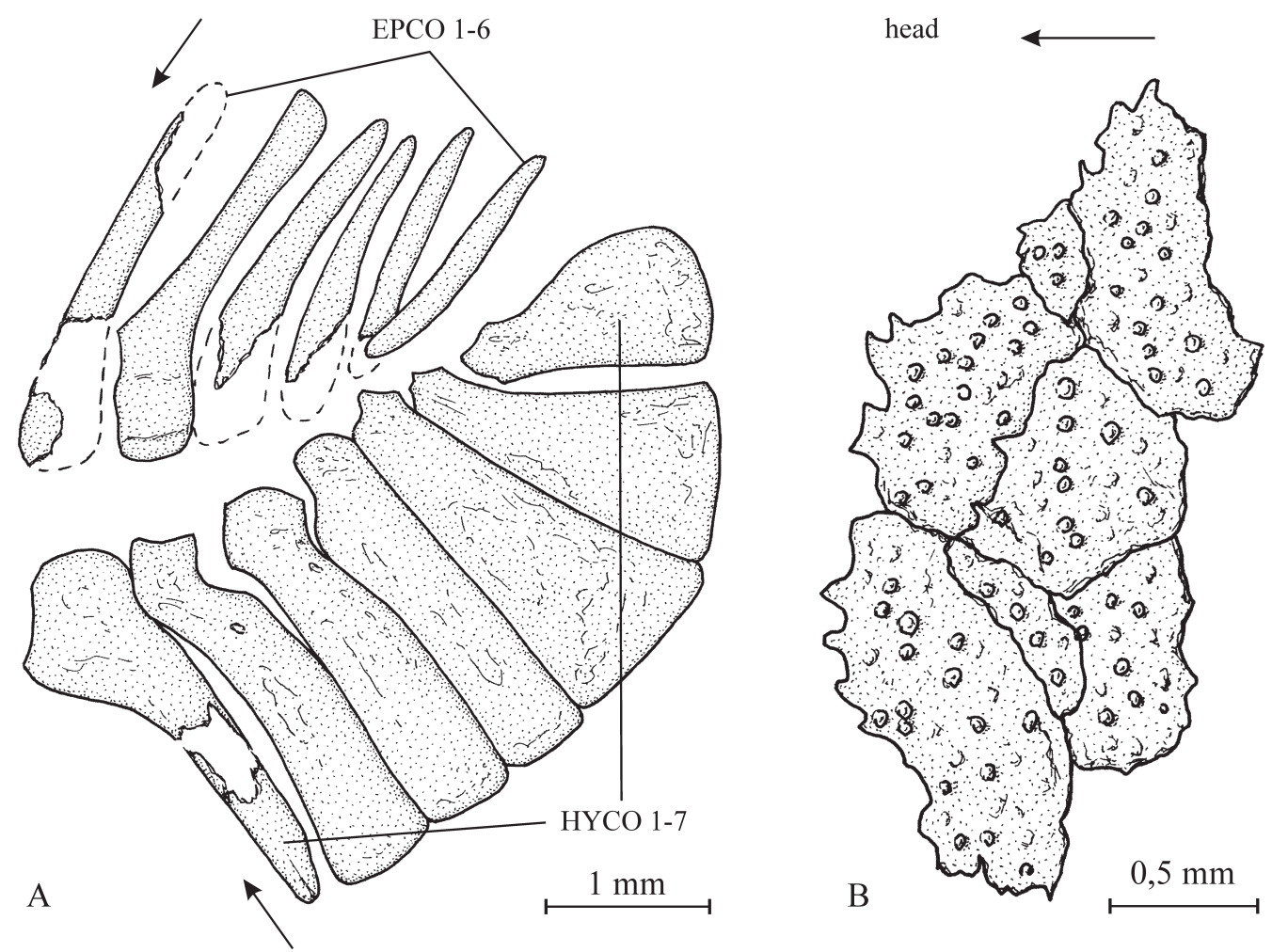

Fig. 21. Rostropycnodus gayeti gen. et sp. nov. A. Caudal skeleton of holotype CLC S-608a. The arrows point on the more external procurrent rays of the caudal fin. B. Body scales of paratype CLC S-595. 
paratype CLC S-595. The first scales of the dorsal margin of the fish are of the same type, but still larger than those on the flanks. Generally, on the other samples, only the tubercles are preserved, but not the outlines of the scales.

Two large, irregularly shaped pelvic scales are visible below the pelvic bones on paratype CLC S-595.

\section{Discussion}

1. Gladiopycnodus gen. nov., Monocerichthys gen. nov. and Rostropycnodus gen. nov. within Neopterygii

Gladiopycnodus gen. nov., Monocerichthys gen. nov. and Rostropycnodus gen. nov. exhibit some very peculiar characters: (1) the mesethmoid is a long and massive bone including the lateral ethmoids, (2) a dermosupraoccipital is present, (3) the preopercle is greatly hypertrophied and is sutured with the hyomandibula, (4) the interopercle and subopercle are lost, (5) a dermohyomandibula is associated with the hyomandibula, (6) the large prearticular bears molariform teeth, (7) the maxilla is plate-like and toothless, (8) there is no supramaxilla, (9) the parasphenoid is elongated and toothless, (10) the pelvic girdle is reduced, (11) a postcoelomic bone is present, (12) the neural and ventral arches are not fused together and they do not entirely surround the notochord, and (13) there are dorsal, pelvic and postcloacal scutes.

Within neopterygian fishes, only Pycnodontomorpha possess these thirteen characters associated. The three new Lebanese genera can be confidently ranged in this superorder.

\section{Gladiopycnodus gen. nov., Monocerichthys gen. nov. and Rostropycnodus gen. nov. within Pycnodontomorpha}

As already mentioned, Nursall (2010) divided Pycnodontomorpha [new usage for the former Pycnodontiformes] into two orders, Gyrodontiformes and Pycnodontiformes [new usage for the former Pycnodontoidei]. Gyrodontiformes are characterized by the presence of two dermosupraoccipitals, by a dentary composed of two branches, one dorsal and one ventral, by their styliform teeth on the premaxilla and the dentary, by their short parasphenoid and by their snout, cheek and gular region being completely covered with small bony tesserae. In Pycnodontiformes, there is only one dermosupraoccipital, the dentary has kept only its ventral branch, the dorsal one being lost, the teeth are incisiform, the parasphenoid is long, and there are true infraorbitals.

The unique dermosupraoccipital, the dentary reduced to the ventral branch, the incisiform teeth borne by the dentary, the long parasphenoid and the infraorbitals of Gladiopycnodus gen. nov., Monocerichthys gen. nov. and Rostropycnodus gen. nov. clearly show that these three fishes belong to the Pycnodontiformes and not to the Gyrodontiformes.

\section{Gladiopycnodus gen. nov., Monocerichthys gen. nov. and Rostropycnodus gen. nov. within Pycnodontiformes}

However, Gladiopycnodus gen. nov., Monocerichthys gen. nov. and Rostropycnodus gen. nov. differ from all other known pycnodontiform fishes by their very peculiar snout anatomy and the presence of a strong pectoral spine articulated with the cleithrum and replacing the lost pectoral fin. These two apomorphies justify the erection of the new family Gladiopycnodontidae.

\section{Gladiopycnodus gen. nov., Monocerichthys gen. nov. and Rostropycnodus gen. nov. within Gladiopycnodontidae}

Monocerichthys gen. nov. seems to be the less evolved gladiopycnodontid genus. The overall morphology of its skull is still rather similar to that of a classic pycnodontiform fish. Other gladiopycnodontid genera 
have a more specialized skull, sometimes differing markedly from the usual pycnodontiform cranial morphotype (pers. obs.). The rostrum of Monocerichthys gen. nov. is not very long and outpaces only slightly the lower jaw level. This outpacing is more pronounced in the other members of the family (pers. obs.).

On the other hand, Gladiopycnodus gen. nov. and Rostropycnodus gen. nov. belong to the more specialized members of Gladiopycnodontidae fam. nov. Indeed, these two Lebanese species had already lost the nuchal horn present in the primitive genera of the family (pers. obs.) and they share three apomorphies not present in primitive members of the lineage, i.e., an extremely elongated rostrum, a greatly hypertrophied anal spine and the first anal pterygiophore being much longer than the following ones.

\section{Gladiopycnodontidae fam. nov. within Pycnodontiformes}

We follow hereafter the phylogeny of Pycnodontiformes established on cranial and postcranial characters by Poyato-Ariza \& Wenz (2002: fig. 43; 2004: fig. 15; 2005: fig. 10). The phylogeny presented by Nursall (1996b: fig. 4, 18) is less detailed and less complete. Kriwet (2005: 62) also proposed a phylogeny of these fishes differing from that of Poyato-Ariza \& Wenz (2002), but being based only on cranial data.

Brembodidae are considered as the most primitive lineage within Pycnodontiformes. Data on this family come from Tintori (1980), Nursall (1999) and Poyato-Ariza \& Wenz (2002). Brembodidae have a deep body, with a dorsal gibbosity or a dorsal spiny expansion formed by the nuchal and dorsal scutes. As in Gyrodontiformes, they have bony tesserae in the gular region and their cheek is completely covered, but here by a greatly hypertrophied first infraorbital and not by bony tesserae. Their premaxilla bears 3 teeth and their dentary 4 or 5 teeth. Their unpaired fins are bordered by fringing fulcra. Their body is completely covered by scales as in Gyrodontiformes.

Macromesodon Blake, 1905 is another primitive pycnodontiform fish with a dorsal angle-shape prominence. Woodward (1918) and Poyato-Ariza \& Wenz (2004) provide information on the genus. Macromesodon has tubular infraorbitals, but still possesses bony tesserae on the cheek, as in Gyrodontiformes, and 4 teeth on the dentary. The tesserae of the gular region are lost. The body is covered by scales only in its anterior region and not in its caudal part. The fringing fulcra on the unpaired fins are lost. These three last characters show that Macromesodon occupies a more apomorphic position in the pycnodontiform phylogenetic tree than Brembodidae.

Gladiopycnodontidae fam. nov. share with more evolved Pycnodontiformes at least three characters that place them in a more advanced position in the phylogeny of the order than Brembodidae and Macromesodon. The infraorbitals are reduced and cover only a small part of the cheek, which is devoid of bony tesserae. The number of teeth on the dentary is reduced (generally 2). There are only two branchiostegal rays that are separated from each other ( pers. obs.).

Pycnodontidae are the largest and most advanced family within Pycnodontiformes. They contain about twenty genera. The most primitive of them is Akromystax Poyato-Ariza \& Wenz, 2005 from the Cenomanian of Lebanon (Poyato-Ariza \& Wenz 2005: fig. 10). The most specialized members of the family are grouped in the subfamily Nursalliinae (Poyato-Ariza \& Wenz 2002: fig. 43). The principal apomorphy of Pycnodontidae is the presence of a brush-like process on the parietal, a structure absent in less evolved Pycnodontiformes and in Gladiopycnodontidae fam. nov.

The systematic position of Gladiopycnodontidae fam. nov. is thus between Brembodidae and Macromesodon on the one hand, and Pycnodontidae on the other hand, a region of the pycnodontiform 
phylogenetic tree containing only the family Coccodontidae (including Trewavasiidae), another highly specialized pycnodontiform lineage from Lebanon.

\section{Gladiopycnodontidae fam. nov., Coccodontidae and Coccodontoidea superfam. nov.}

A comparison between Gladiopycnodontidae fam. nov. and Coccodontidae is thus necessary to define the possible relationships between the two families.

As already said, Monocerichthys gen. nov. is the least specialized gladiopycnodontid genus. On the other hand, Coccodus Pictet, 1850 is the least specialized member of the family Coccodontidae (Capasso et al. 2010: 160-161). Data on Coccodus hereafter mentioned come from Pictet (1850), Davis (1887), Hay (1903), Poyato-Ariza \& Wenz (2002), Kriwet (2005) and principally from our own observations (Taverne \& Capasso, in prep.).

Monocerichthys gen. nov. and Coccodus share a series of characters not present in the other pycnodontiform families: (1) the body is fusiform and without dorsal or ventral apex, (2) the frontal exhibits a small median protuberance, (3) the large supratemporal is articulated with the dermosupraoccipital, the parietal and the dermopterotic, (4) the large posttemporal is sutured to the supratemporal, (5) the very large pectoral girdle is closely associated to the skull, forming a sort of cephalo-thorax, (6) the hypercleithrum is hypertrophied, (7) the cleithrum is greatly hypertrophied with a long and broad ventral branch and a large ventral posterior process, (8) there are less than 20 vertebral segments before the epichordal series, (9) the neural and haemal spines are short, (10) the dorsal fin is short and located in the middle of the back, (11) the anal fin is short and largely separated from the tail and (12) there is never more than one postcloacal scute.

These twelve characters thus can be used to define the new super-family Coccodontoidea superfam. nov., grouping Gladiopycnodontidae fam. nov. and Coccodontidae.

However, in spite of all these resemblances, Coccodontidae and Gladiopycnodontidae fam. nov. cannot be confounded. They greatly differ at the level of their snout morphology, that of Coccodontidae remaining typically pycnodontid. Coccodontidae have also retained a normal pectoral fin with soft rays, whereas Gladiopycnodontidae fam. nov. have the pectoral fin replaced by a strong spine.

\section{Acknowledgements}

We thank Dr. Andrea Pessina, Superintendant of the Soprintendenza per i Beni Archeologici dell' Abruzzo - Chieti, for allowing us to study the fossil fishes of Luigi Capasso's collection. We are grateful to M. Luciano Lullo of the University of Chieti and to M. Hugo De Potter of the Royal Institute of Natural Sciences of Belgium for their technical help. We also thank the anonymous colleagues who have accepted to review our manuscript.

\section{References}

Capasso L.L., Abi Saad P. \& Taverne L. 2009. Nursallia tethysensis sp. nov., a new pycnodont fish (Neopterygii: $\uparrow$ Halecostomi) from the Cenomanian of Lebanon. Bulletin de l'Institut Royal des Sciences Naturelles de Belgique, Sciences de la Terre 79: 117-136.

Capasso L.L., Taverne L. \& Nohra A.R. 2010. A re-description of Hensodon spinosus, a remarkable coccodontid fish (Actinopterygii, $\uparrow$ Pycnodontiformes) from the Cenomanian (Late Cretaceous) of Haqel, Lebanon. Bulletin de l'Institut Royal des Sciences Naturelles de Belgique, Sciences de la Terre 80: 145-162. 
TAVERNE L. \& CAPASSO L., Gladiopycnodontidae fam. nov. (Pisces) from the Cretaceous of Lebanon

Davis J.W. 1887. The fossil fishes of the Chalk of Mount Lebanon, in Syria. Scientific Transactions of the Royal Dublin Society series 2, 3(12): 457-636.

Davis J.W. 1890. On a new species of Coccodus (C. lindstroemi, Davis). The Quaterly Journal of the Geological Society of London 46: 565-568.

Forey P.L., Lu Y., Patterson C. \& Davies C.E. 2003. Fossil fishes of the Cenomanian (Upper Cretaceous) of Namoura, Lebanon. Journal of Systematic Palaeontology 1(4): 227-330. http://dx.doi.org/10.1017/ $\underline{\mathrm{S} 147720190300107 \mathrm{X}}$

Gayet M. 1984. Ichthyoceros spinosus nov. gen., nov. sp., du Cénomanien inférieur de Hakel (Liban) et ses affinités avec le genre Trewavasia (Pisces, Pycnodontiformes, Coccodontidae). Bulletin du Muséum National d'Histoire Naturelle 4e série, 6, section 6, 3: 287-307.

Gayet M., Abi Saad P. \& Gaudant O. 2012. Les fossiles du Liban. Mémoire du temps. Éd. Désiris, Gap.

Hay O.P. 1903. On a collection of Upper Cretaceous fishes from Mount Lebanon, Syria, with descriptions of four new genera and nineteen new species. Bulletin of the American Museum of Natural History 19(10): 395-452.

Kriwet J. 2001. Palaeobiogeography of pycnodontiform fishes (Actinopterygii, Neopterygii). In: Melendez G., Herrera Z., Delvene G. \& Azanza B. (eds) Los fósiles y la paleogeographia. XII Jornadas de la Sociedad Española de Paleontologia: 121-130. Universidad de Zaragoza, Zaragoza.

Kriwet J. 2004. A new pycnodont fish genus (Neopterygii: Pycnodontiformes) from the Cenomanian (Upper Cretaceous) of Mount Lebanon. Journal of Vertebrate Paleontology 24(3): 525-532. http:// dx.doi.org/10.1671/0272-4634(2004)024[0525:ANPFGN]2.0.CO;2

Kriwet J. 2005. A comprehensive study of the skull and dentition of pycnodont fishes. Zittelliana A45: 135-188.

Nursall J.R. 1996a. Distribution and ecology of pycnodont fishes. In: Arratia G. \& Viohl G. (eds) Mesozoic Fishes - Systematics and Paleoecology: 115-124. Verlag Dr. F. Pfeil, München.

Nursall J.R. 1996b. The phylogeny of pycnodont fishes. In: Arratia G. \& Viohl G. (eds) Mesozoic Fishes - Systematics and Paleoecology: 125-152. Verlag Dr. F. Pfeil, München.

Nursall J.R. 1999. The family †Mesturidae and skull of the pycnodont fishes. In: Arratia G. \& Viohl G. (eds) Mesozoic Fishes 2 - Systematics and Paleoecology: 153-188. Verlag Dr. F. Pfeil, München.

Nursall J.R. 2010. The case for pycnodont fishes as the fossil sister-group of teleosts. In: Nelson J.S., Schultze H.-P. \& Wilson M.V.H. (eds) Origin and Phylogenetic Interrelationships of Teleosts: 37-60. Verlag Dr. F. Pfeil, München.

Nursall J.R. \& Capasso L. 2004. Gebrayelichthys (novum), an extraordinary genus of neopterygian fishes from the Cenomanian of Lebanon. In: Arratia G. \& Tintori A. (eds) Mesozoic Fishes 3 - Systematics, Paleoenvironments and Biodiversity: 317-340. Verlag Dr. F. Pfeil, München.

Nursall J.R. \& Capasso L. 2008. Additional specimens from Lebanon reveal more of the structure of the pycnodont fish Trewavasia carinata (Davis, 1887). In: Arratia G., Schultze H.-P. \& Wilson M.V.H. (eds) Mesozoic Fishes 4 - Homology and Phylogeny: 143-166. Verlag Dr. F. Pfeil, München.

Pictet F.-J. 1850. Description de quelques poissons fossiles du Mont Liban. Imprimerie J.-G. Fick, Genève.

Poyato-Ariza F.J. \& Wenz S. 2002. A new insight into pycnodontiform fishes. Geodiversitas 24(1): 139248. 
Poyato-Ariza F.J. \& Wenz S. 2004. The new pycnodontid fish genus Turbomesodon, and a revision of Macromesodon based on new material from the Lower Cretaceous of Las Hoyas, Cuenca, Spain. In: Arratia G. \& Tintori A. (eds) Mesozoic Fishes 3 - Systematics, Paleoenvironments and Biodiversity: 341-378. Verlag Dr. F. Pfeil, München.

Poyato-Ariza F.J. \& Wenz S. 2005. Akromystax tilmachiton gen. et sp. nov., a new pycnodontid fish from the Lebanese Late Cretaceous of Haqel and En Nammoura. Journal of Vertebrate Paleontology 25(1): 27-45. http://dx.doi.org/10.1671/0272-4634(2005)025[0027:ATGESN]2.0.CO;2

Tintori A. 1980. Two new pycnodonts (Pisces, Actinopterygii) from the Upper Triassic of Lombardy (N. Italy). Rivista Italiana di Paleontologia e Stratigrafia 86(4): 795-824.

Woodward A.S. 1918. The Fossil Fishes of the English Wealden and Purbeck Formations. Part 2: 49104. Palaeontological Society, London.

Manuscript received: 19 March 2013

Manuscript accepted: 5 August 2013

Published on: 2 October 2013

Topic editor: Christian de Muizon

Desk editor: Kristiaan Hoedemakers

Printed versions of all papers are also deposited in the libraries of the institutes that are members of the EJT consortium: Muséum National d'Histoire Naturelle, Paris, France; National Botanic Garden of Belgium, Meise, Belgium; Royal Museum for Central Africa, Tervuren, Belgium; Natural History Museum, London, United Kingdom; Royal Belgian Institute of Natural Sciences, Brussels, Belgium; Natural History Museum of Denmark, Copenhagen, Denmark. 